\title{
PROMISING JUSTICE: CONTRACT (AS) SOCIAL RESPONSIBILITY
}

\author{
JONATHAN C. LIPSON*
}

Contracts in a variety of contexts-from multinational supply chain agreements to movie-production deals-increasingly include promises on such "social responsibility" matters as human trafficking, environmental sustainability, and socio-demographic diversity. These terms literally promise justice:

Can they deliver?

This paper makes three claims about the use of contract to achieve social responsibility (which I abbreviate "KSR"). First, KSR can be seen as a response to "vertical deconstruction," the erosion of intra-firm and social orders that historically generated and transmitted non-commercial social norms. Second, as such, KSR terms will be legally un(der)-enforceable: Like better-studied relational contracts, KSR will blend enforceable and unenforceable terms to achieve govemance, risk-sharing, and educative goals. Third, although KSR may be more effective than more popular mechanisms, in particular corporate social responsibility, KSR is not a panacea, and presents risks of cooptation and fragmentation often associated with soft-law regimes.

Introduction

I. What is KSR? ........................................... 1116

A. Structure \& Substance............................... 1117

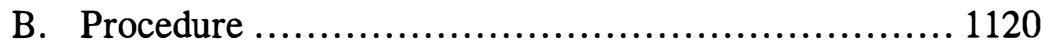

1. Monitoring ..................................... 1121

2. Remedy ...................................... 1123

a. Expectation ................................. 1124

b. Consequential Damages-Reputational Harm ... 1125

c. Liquidated Damages and Indemnification........ 1127

d. Specific performance ........................... 1128

e. Rescission ................................... 1129

Harold E. Kohn Professor of Law, Temple University-Beasley School of Law. This project has benefited from the suggestions of, and discussions with, many people, including Lisa Bernstein, Hanoch Dagan, Jeff Dunoff, Jill Fisch, Cristie Ford, Craig Green, Steve Kobrin, Tim Lytton, Stewart Macaulay, Kathleen Noonan, Kish Parella, Rachel Rebouche, Bill Simon, David Snyder, and Bill Whitford. Dina Bleckman, Danielle Froschauser, Erica Maier-and Erin McKevitt provided excellent research and administrative support. Special thanks go to students in my Advising the Multinational Corporation course, at Temple University-Japan, who were subjected to a full semester of this project. Earlier versions have benefited from comments received at Tsinghua University School of Law, Temple University-Japan, and (in electronic form) on the Concurring Opinions blog. Errors and omissions are mine, alone. (C) 2019, Jonathan C. Lipson, all rights reserved. 
C. The Problem of Un(der)-enforceability-"Interior"

Remedies. ............................................... 1130

II. Why KSR? ......................................... 1133

A. Normative Pressure.............................. 1133

1. Soft Law: Norm Generation Regimes .............. 1133

2. Hard Law ....................................... 1135

3. Litigation Risk ................................ 1138

4. Reputational Sanctions and Rewards............... 1140

B. Vertical Deconstruction v. Normative Integration ....... 1141

III. Promising Justice: How Might KSR Actually Work? ......... 1145

A. Form v. Norm: Relational Contracting Theory ......... 1146

B. Contingency and Contracting for Normative Innovation 1149

C. Granularity, Specificity and the Expressive and

Educative Functions of Contract........................ 1151

D. The Problem of Opportunism ......................... 1155

E. Problems of Cooptation and Fragmentation.............. 1156

Conclusion........................................................ 1160

\section{INTRODUCTION}

"I have two words for you," actress Frances McDormand declared at the end of her 2018 Oscar acceptance speech: "inclusion rider." ${ }^{1}$ In doing so, she sought to inspire other A-list actors to negotiate for contract terms to increase diversity and inclusion in movie productions. She probably did not realize that she was also inviting us to rethink the role that contract plays in social order.

But she was, because she was making a very public statement about what we may call "contract śocial responsibility" ("KSR," to distinguish it from "CSR", the abbreviation for KSR's weaker relative, "corporate social responsibility"). KSR harnesses ostensibly enforceable contract terms to address social, economic, and environmental problems conventionally remitted to public law and agencies. McDormand's inclusion rider, for example, would use contract terms to redress racial and gender discrimination that the Equal Employment Opportunity Commission might otherwise address under Title VII of the Civil Rights Act of $1964 .^{2}$

1. Martin Belam \& Sam Levin, Woman Behind 'Inclusion Rider' Explains Frances McDormand's Oscar Speech, THE GUARDIAN (Mar. 5, 2018), https://www.theguardian.com/film/2018/mar/05/what-is-an-inclusion-rider-francesmcdormand-oscars-2018 [https://perma.cc/JPW5-8C47].

2. The Equal Employment Opportunity Commission, for example, plays a role in enforcing the Civil Rights Act of 1964, which bars discrimination against a person on the basis of race, color, religion, national origin, or sex. See 42 U.S.C. $\S$ 
KSR goes well beyond workplace diversity. General Motors' standard-form supply-chain agreement, for example, apparently. requires its suppliers to agree not to use "child, slave, prisoner or any other form of forced or involuntary labor." 3 Hewlett Packard's "supplier sustainability requirements" incorporate elaborate environmental compliance standards. ${ }^{4}$ The oldest example I have found is the Beatles' 1965 performance agreement, which provided that the group will "not be required to perform in front of a segregated audience." 5

Taken seriously, KSR terms appear to seek normative social change. As such; they are unlikely to be enforceable in any ordinary sense. Black-letter contract measures such as "expectation" or "consequential" damages will be difficult to price because the harm from breach will have indeterminate commercial effects. If a seller to GM breaches its standard terms by using forced labor, for example, that may harm GM's reputation, but it would not necessarily increase the cost, or reduce the quality, of the promised goods to GM. Courts have recognized that reputational harm may be a form of consequential damage, but they do so reluctantly because causation is tricky and pricing is speculative. ${ }^{6}$ Specific performance seems even less plausible, since KSR terms will often involve personal matters such as governance or value-choice, which may be even more daunting for judges than fixing damages. ${ }^{7}$

Surprisingly, legal scholars have largely ignored KSR. Emerging "new governance" literature often extols the virtues of alternative and hybrid mechanisms to advance normative agendas. ${ }^{8}$ While this literature

2000e-2(a) (2012); see also Laws Enforced by EEOC, U.S. EQUAL EMP. OPPORTUNITY CoMm'N, https://www.eeoc.gov/laws/statutes/ [https://perma.cc/XY9V-NQH5].

3. Anti-Slavery and Human Trafficking Statement, GEN. MOTORS Co., https://www.gm.com/content/dam/company/archive/docs/legal/General_Motors_Comp any_Anti_Slavery_And_Human_Trafficking_Statement.pdf [https://perma.cc/YYV5$88 \mathrm{H} 7$ ].

4. Supplier Social \& Environmental Responsibility Agreement, HewLETTPACKARD, (Nov. 2015), http://h20195.www2.hp.com/V2/GetDocument. aspx?docname $=$ c04900239 [https://perma.cc/TMW6-Z7YE].

5. The Beatles Banned Segregated Audiences, Contract Shows, BBC NEws, (Sept. 18, 2011), https://www.bbc.com/news/entertainment-arts-14963752 [https://perma.cc/XFA3-DEC8].

6. See Redgrave v. Boston Symphony Orchestra, Inc., 855 F.2d 888, 89294 (1st Cir. 1988) (partly reversing a jury award of consequential damages for reputational harm from breach of contract).

7. See generally Jonathan C. Lipson, Something Else: Specific Relief for Breach of Human Rights Terms in Multinational Supply Chain Agreements, 68 AM. U. L. REV. 1751 (2019).

8. For a small sample, see Charles F. Sabel \& William H. Simon, Minimalism and Experimentalism in the Administrative State, 100 GEO. L.J. 53, 62 
sometimes suggests that contract plays a role here, it never seriously considers what that means. ${ }^{9}$ At the same time, contracts scholars have

(2011). See also LAw AND NEW GovernanCE IN THE EU AND THE US 2 (Grainne de Burca \& Joanne Scott eds., 2006); Kenneth W. Abbott \& Duncan Snidal, Strengthening International Regulation Through Transnational New Governance: Overcoming the Orchestration Deficit, 42 VAND. J. TRANSNAT'L L. 501, 508-09 (2009); Charles F. Sabel \& William H. Simon, Contextualizing Regimes: Institutionalization as a Response to the Limits of Interpretation and Policy Engineering, 110 MrCH. L. REv. 1265 (2012); Joanne Scott \& Susan Sturm, Courts as Catalysts: Re-Thinking the Judicial Role in New Governance, 13 ColuM. J. EUR. L. 565, 565 (2007); William H. Simon, Toyota Jurisprudence: Legal Theory and Rolling Rule Regimes, in LAW AND NEW GoVERNANCE IN THE EU AND THE US (Grainne de Burca \& Joanne Scott eds., 2006); Jason M. Solomon, Law and Governance in the 21st Century Regulatory State, 86 TEX. L. REV. 819,823 (2008) (book review). The best developed example of this work salient to contract (as) social responsibility looks at human rights terms in supply chain agreements. See, e.g., 'Kishanthi Parella, Improving Social Compliance in Supply Chains, 95 NOTRE DAME L. REV. (forthcoming 2019) (evaluating the use of reputational mechanisms for improving corporate compliance with human rights); Kishanthi Parella, Outsourcing Corporate Accountability, 89 WASH. L. REV. 747, 750 (2014) (arguing that human rights obligations may be "outsourced" through supply chain agreements).

9. A good example is Fabrizio Cafaggi, The Regulatory Functions of Transnational Commercial Contracts: New Architectures, 36 FordHAM INT'L L.J. 1557,1564 (2013). While he starts from the observation that "[t]ransnational commercial contracts have also become vehicles of implementation of public international regulation," his thick description conceals any interest in contract theory or doctrine. Id. at 1564-66. Verbruggen takes a similar approach. Paul Verbruggen, Regulatory Governance by Contract: The Rise of Regulatory Standards in Commercial Contracts, 35 RECHT DER WERKELIJKHEID 79, 93-96 (2014) (arguing that "contract law imposes constraints on the use of commercial contracts as a regulatory device"). See also DOREEN MCBARNET \& MARINA KURKCHIYAN, CORPORATE SOCIAL RESPONSIBILITY Through Contractual Control? Global Supply Chains and "OtherRegulation," 59 (Doreen McBarnet et al. eds., 2007) (arguing that contract in this context is no more than "soft law"); Eli Bukspan, Extreme Makeover - Contract Law Edition: A New Home for Human Rights and Social Responsibility Ressons from Israel), 7 INTERCULTURAL HUM. RTS. L. REV. 329, 329 (2012) (arguing that contract law "may emerge as an agent of real social and legal change, both because it deals with the most common daily interactions and because of its growing social stature at a time of a weakening state and increasingly stronger private players"); Deborah Burand, Contracting for Impact: Embedding Social and Environmental Impact Goals into Loan Agreements, 13 N.Y.U. J.L. \& Bus. 775, 782 (2017) (providing “a catalogue of trends in embedding social and environmental impact objectives into the loan documentation of impact investments").

For a recent and thoughtful exception focusing on ethical issues in contracting, see David V. Snyder, The New Social Contracts in International Supply Chains, 68 AM. U. L. REv. 1869, 1910 (2019) (discussing "moral" aspects of contract terms seeking to protect workers' rights). Michael Vandenbergh's work on environmental governance looks at the role that contract plays in environmental protection, though focuses more on governance than contract issues. See Michael P. Vandenbergh, The New Wal-Mart Effect: The Role of Private Contracting in Global Governance, 54 UCLA L. Rev. 913, 918 (2007); see also Michael P. Vandenbergh, Private Environmental Governance, 99 CORNELL L. REV. 129, 133 (2013); Michael P. Vandenbergh, The Private Life of Public Law, 105 Colum. L. Rev. 2029, 2051-52 
struggled to explain the value that formal contract-as written instrument and as black letter doctrine-adds to the transactions and relationships of which it is a part, ${ }^{10}$ without ever considering the possibility that contract can be a way to deliver more than merely promised goods, services, and money. KSR indicates that, in some cases, contract may also seek to deliver normative social change.

This paper begins to fill these gaps by developing a sustained contract analysis of KSR terms. I make three claims about them.

First, I argue that KSR is a response to what we may call "vertical deconstruction," the flattening of organizational hierarchies and the disruption of social structures that once produced and enforced norms which are, today, often the subject of KSR terms. ${ }^{11}$ This is most pronounced in global supply chains sometimes implicated in human rights abuses. Vertical deconstruction has contributed to what John Ruggie has notably called "governance gaps" that "provide the permissive environment for wrongful acts by companies of all kinds without adequate sanctioning or reparation." ${ }^{12}$ KSR seeks to articulate "sanctions" and "reparations" for normative offenses arising within these gaps at the level of the individual promisor and promisee.

But vertical deconstruction-and KSR-involve more than global supply chains. All market actors face the "make or buy" decision, and

(2005) (analyzing contracts that include environmental provisions). Li-Wen Lin has also begun to explore the difficult issue of third-party beneficiary doctrine presented by KSR terms. Li-Wen Lin, Legal Transplants Through Private Contracting: Codes of Vendor Conduct in Global Supply Chains as an Example, 57 AM. J. Comp. L. 711, 743 (2009).

10. See, e.g., Scott Baker \& Albert Choi, Contract's Role in Relational Contract, 101 VA. L. REV. 559, 561 (2015) ("If the parties perform obligations, or fulfill their promises, out of the fear of reputational or relational sanctions, why do they bother to write enforceable formal contracts in the first place?").

11. "Vertical deconstruction" is related to, but broader than, the "vertical disintegration" observed by Gilson et al. See Ronald J. Gilson et al., Contracting for Innovation: Vertical Disintegration and Interfirm Collaboration, 109 Colum. L. REv. 431, 435 (2009). As explained in Part II.B, below, I do not think that the structural changes that drive KSR are the product of anything that has "disintegrated." Instead, what we see are changing social and organizational structures, and uses of those structures, with contract as a partial but important substitute for the control those structures once created. A good discussion of the underlying phenomena appears in Gillian HADFIELD, RULES FOR a Flat WORLD: Why HuMANS INVENTEd LAW AND How to REINVENT IT FOR A COMPLEX GLOBAL ECONOMY (2016).

Incidentally, and for the sake of clarity: I do not suggest that KSR terms in fact change social norms. Determining whether that is the case empirically is a task for a later day, and perhaps other methodologies. I mean only that such terms purport to do so.

12. John Ruggie (U.N. Secretary-General's Special Representative for Business and Human Rights), Rep. of the Special Representative of the SecretaryGeneral on the Issue of Human Rights and Transnational Corporations and Other Business Enterprises: Protect, Respect, and Remedy: A Framework for Business and Human Rights, I 3, U.N. Doc. A/HRC/8/5 (Apr. 7, 2008). 
that decision implies different means of generating and conveying social norms. The Hollywood studio system in which Frances McDormand might once have worked has been replaced by negotiated performance contracts to which she would, today, attach inclusion riders. Indeed, free-agency in sports, executive compensation contracts in the C-suite, and the "gig economy" generally bespeak the deconstruction of social orders that might once have produced and enforced norms on matters such as diversity, distributive economics, and the environment. ${ }^{13}$ Where once social norms may have been driven through a firm or social hierarchy, they are today increasingly transmitted across a "flattened" world by contract. Contract, in short, is often a substitute for (or complement to) command and community in generating and disseminating social norms.

Second, the fact that KSR terms may be un- or under-enforceable is neither surprising nor especially problematic. I situate KSR in the literature on relational contract theory which emanated from Stewart Macaulay's path-breaking insight that contracts are often legally unenforced or unenforceable, inviting the question: why bother with contract at all? ${ }^{14}$ Seeking to answer this question, Lisa Bernstein, ${ }^{15}$ Ronald Gilson and coauthors, ${ }^{16}$ and Matt Jennejohn, ${ }^{17}$ among others, have argued that promissory relationships of any significance often

13. To be sure, older hierarchical orders hardly guaranteed desirable outcomes on matters of social responsibility: vertically integrated conglomerates might have been able to transmit norms efficiently, but we may not like those norms, today. This, however, is simply another way of explaining why efforts to use contract to achieve social responsibility may be appealing. See infra Part II.A.

14. Stewart Macaulay, Non-Contractúal Relations in Business: A Preliminary Study, 28 AM. Soc. REv. 55, 57 (1963). Robert Scott has noted that Macaulay's paper may be the most widely cited contracts paper in modern history. Robert E. Scott, The Promise and the Peril of Relational Contract Theory, in REvISITING THE CONTRACTS SCHOLARSHIP OF STEWART MACAULAY 105, 105 (Braucher et al. eds., 2013) (observing that Macaulay's Non-Contractual Relations is the "most widely cited paper on contract law of the past 50 years"). See also Baker \& Choi, supra note 10.

15. See, e.g., Lisa Bernstein, Beyond Relational Contracts: Social Capital and Network Governance in Procurement Contracts, 7 J. Legal Analysis 561, 563 (2015).

16. See, e.g., Gilson et al., supra note 11, at 435; see also Ronald J. Gilson, Charles F. Sabel \& Robert E. Scott, Braiding: The Interaction of Formal and Informal Contracting in Theory, Practice, and Doctrine, 110 Colum. L. REv. 1377, 1415-16 (2010) [hereinafter Braiding]; Ronald J. Gilson, Charles F. Sabel \& Robert E. Scott, Contract and Innovation: The Limited Role of Generalist Courts in the Evolution of Novel Contractual Forms, 88 N.Y.U. L. REv. 170, 172-74 (2013) [hereinafter Contract and Innovation]; Ronald J. Gilson, Charles F. Sabel, \& Robert E. Scott, Text and Context: Contract Interpretation as Contract Design, 100 Cornell L. ReV. 23, 96-97 (2014) [hereinafter Text and Context].

17. See Matthew Jennejohn, The Private Order of Innovation Networks, 68 STAN. L. REv. 281, 292 (2016). 
involve a mix of both enforceable and unenforceable elements meant to achieve governance, educative, and risk-sharing goals.

So, too, with KSR, which appears to involve a kind of "braiding" like that found by Gilson et al. in contracts for technological innovation. ${ }^{18}$ In the case of KSR, the innovation would involve not technology, but instead behavior around potentially sensitive social and political matters, such as the treatment of labor and the environment. KSR terms thus appear to interweave some promises that are likely to be enforceable, such as indemnification for breach, ${ }^{19}$ with other promises that are probably not, such as those empowering a buyer to require termination of a breaching seller's managers. ${ }^{20}$ The specificity, granularity, and potential recourse created by this mix of enforceable and unenforceable terms can have both instrumental and expressive power that induces greater attention to the underlying norms from the parties' operational and legal personnel than competing regimes, such as corporate social responsibility (CSR). At the same time, their underenforceability will give parties sufficient flexibility to permit the experimentation and adaptation necessary for KSR terms to move toward their normative promise.

Third, despite its promise, we should not exaggerate KSR's capacity to change social norms. Many worry that voluntary and extralegal efforts like CSR are little more than aspirational smokescreens because they generally create no legally enforceable obligations. ${ }^{21}$ Indeed, CSR may actually backfire by coopting other, perhaps more effective, "hard" law efforts to solve difficult social problems. ${ }^{22}$ KSR's instrumental and expressive elements-its formal and informal features-may be more effective in certain respects than CSR, but they are not a panacea: there is, after all, no guarantee that KSR promisees would seek to enforce such terms even if they could. Instead, KSR is simply a new and potentially powerful tool in efforts to do well while also doing good. The goal of this paper is to explore the contractual

18. Gilson, Sabel \& Scott, Braiding, supra note 16.

19. See infra discussion Part I.B.2.

20. See infra discussion Part I.B.2.

21. Leigh A. Payne \& Gabriel Pereira, Corporate Complicity in International Human Rights Violations, 12 ANN. REv. L. \& Soc. SCI. 63, 68 (2016) (“[A]t best voluntary principles have done little to diffuse understanding of business obligations under international human rights law. At worst, they signal to businesses and states that these obligations are voluntary, thereby undermining efforts to strengthen global human rights protections.").

22. Orly Lobel, The Paradox of Extralegal Activism: Critical Legal Consciousness and Transformative Politics, 120 HARV. L. REV. 937, 939 (2007); see also Orly Lobel, The Renew Deal: The Fall of Regulation and the Rise of Governance in Contemporary Legal Thought, 89 MiNN. L. REv. 342, 343-44 (2004). 
characteristics of this tool in order to better understand whether and how the promise of contract social responsibility can be realized.

This paper proceeds in three main parts. Part I sketches the substance of KSR terms and some practical and doctrinal limits to their use. Part II explains the normative and structural pressures to use contract in this way. Part III explains how these terms are likely to operate in a relationalist sense, and how those relational realities will influence the efficacy of KSR terms.

\section{WHAT IS KSR?}

Contract terms are "socially responsible" if they are an element of an instrument that purports to be an enforceable contract and that seek explicitly to achieve social, economic, or environmental goals through the performance of such terms. KSR terms are related to, but distinct from, other mechanisms that have been better studied, in particular "corporate social responsibility" (CSR). CSR is simply statements of corporate policy broadcast to the world. It produces legal instrumentsresolutions, bylaw amendments-that are merely "aspirational in nature," and largely unenforceable legally against the corporation or its agents (e.g., directors and officers). ${ }^{23}$ While it captures increasing public interest, ${ }^{24}$ it remains "soft" law that exhorts corporate actors to account for the welfare of a corporation's many stakeholders, but creates no legal penalty for failing to do so. ${ }^{25}$

At the same time, many have long worried that CSR vests managers with too much discretion, and is thus, in Adolf Berle's famous observation, "an invitation not to law or orderly government, but to a process of economic civil war." ${ }^{\text {26 }}$ Although KSR terms will present serious issues of monitoring and enforceability, their most

23. See Nat'l Consumers League v. Wal-Mart Stores, Inc, 2016 WL 4080541 , at $* 1, * 2$ (D.C. Super. Ct. July 22,2016 ).

24. The Business Roundtable, for example, recently announced that corporations should no longer maximize shareholder value at the expense of other stakeholders but should instead "serve all Americans." Business Roundtable Redefines the Purpose of a Corporation to Promote 'An Economy That Serves All Americans,' Bus. RoundTABLE (Aug. 19, 2019), https://www.businessroundtable.org/businessroundtable-redefines-the-purpose-of-a-corporation-to-promote-an-economy-that-servesall-americans [https://perma.cc/9K2F-2HLG].

25. Cheryl L. Wade, Effective Compliance with Antidiscrimination Law: Corporate Personhood, Purpose and Social Responsibility, 74 WASH. \& LEE L. REV. 1187,1192 (2017) (defining CSR to include the impact of corporate activity on a corporation's constituencies or even on "general social wellbeing"); see also Archie B. Carroll, Corporate Social Responsibility: Evolution of a Definitional Construct, 38 Bus. \& SoC'Y 268, 268 (1999) (discussing the evolution of corporate social responsibility).

26. A. A. Berle, Jr., For Whom Corporate Managers are Trustees, 45 HARV. L. REV. 1365, 1369 (1932). 
obvious virtue over CSR is their potential to be legally enforceable, because they take the form of an instrument-a contract-for the breach of which legal systems purport to provide a remedy. ${ }^{27}$ Not so for CSR.

At a high level of generality, we can distinguish between substantive and procedural KSR terms. Substantive KSR terms are akin to those noted in the introduction: they constitute express promises to act (or to refrain from acting) in a way designed to have an important social or environmental impact in addition to, or apart from, the commercial interests of the parties, themselves. Procedural KSR terms will be those elements of the contract that seek to implement the substantive terms.

This Part briefly surveys important KSR provisions, and doctrinal and practical limits to their efficacy, limits which then invite questions about why and how market actors use these terms, matters explored in Parts II and III.

\section{A. Structure \& Substance}

Unlike the conventional bilateral contract, KSR terms deliberately contemplate the welfare of persons not parties to the contract, or conditions such as environmental sustainability, that are directed at society in general. Unlike typical third-party beneficiaries, however, beneficiaries of KSR terms may be diffuse, ill-defined, perhaps unknown, except in principle to the primary parties to the contract. ${ }^{28}$ The terms will seek to achieve a "social" goal that has, by hypothesis, been unattainable by conventional institutional mechanisms, presumptively government, and which may be tangential to the main subject matter of the contract. Often, the subject matter of the terms will be politically contested.

27. RESTATEMENT (SECOND) CONTRACTS $§ 1$ (AM. LAW INST. 1981). I put to one side the rise of "benefit corporations," the law of which may confer on shareholders limited rights against the corporation if it fails to adhere to a stated social responsibility goal. These rights may be quite limited, however. See David G. Yosifon, Opting Out of Shareholder Primacy: Is the Public Benefit Corporation Trivial?, 41 DEL. J. CORP. L. 461, 485 (2017) (observing that Delaware's public benefit corporation statute "strictly limits enforceability of the governance standards of a public benefit corporation" (emphasis omitted) (citing 8 DEL. CODE ANN. tit. 8, § 365(b) (2019)).

28. I do not consider here whether, or to what extent, ostensible beneficiaries of KSR terms may sue promisors or promisees under the third-party beneficiary doctrine. The Restatement (Second) of Contracts provides that an "intended beneficiary" of a contract may be able to sue to enforce a contractual promise under some circumstances. RESTATEMENT (SECOND) CONTRACTS § 302(1) (AM. LAw INST. 1981). To this point, courts have been reluctant to view supplier's employees under supply chain agreements as "intended beneficiaries" of KSR promises regarding workplace conditions by the promisor-employers. Doe I v. Wal-Mart Stores, Inc., 572 F.3d 677, 681-82 (9th Cir. 2009). 
In its simplest form, KSR terms form a triangle:

\section{Contract Social Responsibility General Structure}

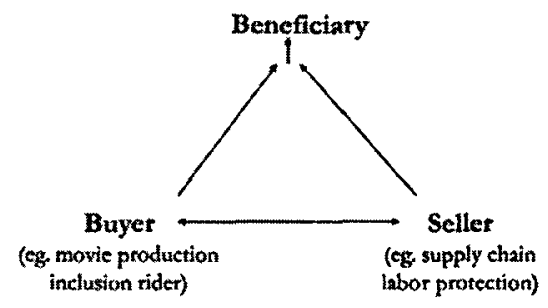

Here, the buyer or the seller under a conventional bilateral contract agrees to the purchase or sale of goods or services. In addition, however, one of the parties promises to act (or to refrain from acting) in some way that benefits third parties or society as a whole.

In many cases, substantive KSR terms will be "insourced" from other standard-setting organizations. ${ }^{29}$ Rather than design terms from scratch, the promisor may agree to adhere to social responsibility standards set by, for example, the International Organization for Standardization, ${ }^{30}$ the Global Reporting Initiative, ${ }^{31}$ or Social

29. Cafaggi reports that "[i]ncorporation by reference is one dimension of a much broader phenomenon of the increasing interaction between transnational contracting, transnational regulation, and certification. The inclusion of regulatory provisions is often combined with reference to one or more certification schemes." Cafaggi, supra note 9, at 1561. As Cata-Backer explains:

With respect to the management of suppliers, multinational corporations tend to focus regulatory efforts through contracts and agreements with individual suppliers that incorporate the multinational corporation's framework for ethical standards. In some cases additional supplier standards are specified. These standards are stakeholder oriented. They focus primarily on the perceived tastes and expectations of consumers, investors, and the financial markets. They are developed in conjunction, or at least with some consideration of the agendas and projects of legitimate and influential elements of civil society (influential, that is, with consumers, investors or financial markets, or to some extent, the state).

Larry Catá Backer, Economic Globalization and the Rise of Efficient Systems of Global Private Law Making: Wal-Mart as Global Legislator, 39 CoNN. L. REV. 1739, 1752-53 (2007).

30. The International Standards Organization provides its own certification specifically dedicated to social responsibility (ISO 26000). ISO 26000 Social Responsibility, INT'L ORG. FOR STANDARDIZATION, https://www.iso.org/iso-26000social-responsibility.html [https://perma.cc/PHB3-W59Q] (providing standards and guidelines for companies to define and implement corporate social responsibility). 
Accountability International. ${ }^{32}$ The promisor may agree to join an organization such as the Responsible Business Alliance, whose members must conform to that group's standards and code of conduct. ${ }^{33}$ Similarly, KSR terms may be the product of a promise to obtain and maintain certain types of social responsibility certifications, such as on fair trade ${ }^{34}$ or the environment. ${ }^{35}$

Insourcing substantive terms reflects two important attributes of KSR. First, these terms may be tangential to the commercial core of the contract. Parties that insource these standards may do so because the standard-setting organizations have developed expertise that the parties lack. The parties will have expertise as to the commercial elements of the transaction, e.g., the sale of goods or services. But parties may insource substantive KSR terms because other organizations have expertise in social responsibility that the parties, themselves, do not. Moreover, the terms may reflect norms that are not shared by the

31. About GRI, GRI, https://www.globalreporting.org/information/aboutgri/Pages/default.aspx [https://perma.cc/P9D9-P5EY] (setting forth guidelines and reporting standards for sustainability).

32. SA8000, for example, assesses social accountability in both factories and organizations. SA8000 Standard, Soc. ACCOUNTABILITY INT'L, http://www.saintl.org/index.cfm?fuseaction $=$ Page. ViewPage\&PageID $=1689$

[https://perma.cc/V5NM-3GAV]. It evaluates each organizations' involvement in nine areas related to social accountability: (1) Child Labor, (2) Forced or Compulsory Labor, (3) Health and Safety, (4) Freedom of Association and Right to Collective Bargaining, (5) Discrimination, (6) Disciplinary Practices, (7) Working Hours, (8) Remuneration, and (9) Management System. Id.

33. Standards and Accountability, Responsible Bus. Alliance, http://www.responsiblebusiness.org/code-standards-and-accountability/

[https://perma.cc/855G-H5B8] ("RBA members are required to adhere to a core set of requirements and are held accountable to them."). Similarly, the pharmaceutical industry has its own unique set of standards and principles that organizations can choose to adhere to throughout their supply chain. Through the "Pharmaceutical Supply Chain Initiative," organizations can express their commitment to ethics, labor, health and safety, environment, and management systems. See Pharmaceutical Industry Principles for Responsible Supply Chain Management, PHARMACEUTICAL SUPPLY ChaIN INITIATIVE (2015), https://pscinitiative.org/home [https://perma.cc/G6AXMJWS]. The kosher certification system is a similar example. See TIMOTHY D. LyTton, Kosher: Private Regulation IN THE Age of INDUSTRIal FoOD 100-01 (2013).

34. Fair Trade for Business, FAIR TRADE CERTIFIED, https://www.fairtradecertified.org/business?gclid=Cj0KCQjwjtLZBRDLARIsAKT6fX ybBwZRUvYDdG_kJcW17frRAx8eqx51NaHa8S_Nh_xDfbeT3s7jfllaAm0EEALw_wc B [https://perma.cc/JU87-FJ5D].

35. Green Building Leadership is LEED, LEADERSHIP IN ENERGY \& ENVTL. DESIGN, https://new.usgbc.org/leed [https://perma.cc/TB87-54GH]; see also Adrian D'Arcy, Project Owners and the AIA's Sustainable Project Contract Documents, CONSTRUCTION LAW., Winter 2017, at 21 ("Sustainable design and construction (otherwise known as 'green building') is an evolving and growing sector of the building industry that presents new challenges and legal considerations for the owner ('Owner'), the architect ('Architect'), and the contractor ('Contractor').). 
parties. Indeed, at least one reason a company like Wal-Mart may require suppliers to commit contractually to honor its code of conduct is because Wal-Mart prefers its (stated) conduct to that of its suppliers. ${ }^{36}$.

Second, the rapid development of these sorts of terms suggests a commitment to normative innovation by the parties. Members of the Responsible Business Alliance, for example, must make a "commitment to continuous improvement." ${ }^{37}$ Twenty years ago, it is unlikely that contracts included representations about employees' sexual misconduct. ${ }^{38}$ Today, it appears that companies increasingly use a "Weinstein clause" ${ }^{39}$ to address concerns generated by the "\#MeToo movement." ${ }^{" 40}$ More generally, the globalization of economic activity implies interactions that may require ongoing normative adjustment, which may be articulated in market actors' contracts.

\section{B. Procedure}

To introduce these sorts of terms into contracts is to invite questions about how, exactly, they will work. Contracts among sophisticated parties inevitably include a number of procedural terms involving, for example, parties' rights to information and protocols in the event of breach. Often, these terms are boilerplate, and just as often they are intended to contract around the default rule provided by applicable background law. Whether, or to what extent, substantive KSR terms work will therefore turn on what sorts of procedural

36. See Backer, supra note 29 , at $1755-56$ (“[Wal-Mart's] Standards for Suppliers is the principle vehicle through which Wal-Mart deploys its contractually bounded relationships with its suppliers to construct a deeper, and more intimate relationship between ostensibly independent actors, a relationship based on conformity to behavior norms in the conduct of supplier operations as well as the more traditional focus on the quality of the product to be delivered.").

37. ResPonsible Bus. AlliANCE, supra note 33 ("[S]ustainability doesn't happen overnight, and companies will always face new or chronic challenges to protect the rights and wellbeing of workers and communities in their supply chains.").

38. Historically, it appears that claims of employee sexual misconduct were not considered "material" for securities law disclosure purposes. See Jaclyn Jaeger, The 'Weinstein Clause': M\&A Deals in the \#MeToo Era, COMPLIANCE WEEK (Oct. 12, 2018, 8:45 AM), https://www.complianceweek.com/the-weinstein-clause-manda-dealsin-the-metoo-era/2113.article [https://perma.cc/D9CX-VJKC]; Nabila Ahmed, Wall Street Is Adding a New 'Weinstein Clause' Before Making Deals, BloOMBERG (Aug. 1, 2018, 11:29 AM), https://www.bloomberg.com/news/articles/2018-08-01/-weinsteinclause-creeps-into-deals-as-wary-buyers-seek-cover [https://perma.cc/HM7H-HHZG].

39. Jaeger, supra note 38; Ahmed, supra note 38.

40. Jaeger, supra note 38 (noting that \#MeToo representations have appeared in a variety of industries including: restaurant, retail, biotechnology, and asset management); see also, e.g., Del Frisco's RESTAURANT Group, INC., PURCHASE AgreEment and Plan of Merger (May 2018); Forest City Realty TR., INC., AGREEMENT AND Plan OF MERGER (July 2018). 
mechanisms the parties have agreed to use (or that the law otherwise provides), and whether those mechanisms have legal effect. Viewed in these terms, KSR becomes puzzling because although the terms may appear in instruments that look like contracts, performance will be difficult for the parties to monitor and for the courts to enforce in any ordinary sense.

\section{MONITORING}

In order to determine whether a promisor has kept its KSR promise, the promisee will want information about not only the promisor but, in many cases, others with whom the promisor has dealt, such as its suppliers. This is an especially difficult problem in multinational supply chain agreements because supply chains can be quite long, and the ultimate buyer/promisee is unlikely to have meaningful access to information about remote parties in it. ${ }^{41}$

Perhaps the most ambitious effort to address this problem appears in model contract terms (Model Terms) to protect the human rights of those employed by firms that are parties to supply chain agreements (SCA) developed by the Working Group to Draft Human Rights Protections in International Supply Contracts (Working Group) of the Business Law Section of the American Bar Association. ${ }^{42}$ The Model Terms seek to put teeth into substantive KSR standards articulated in the ABA Model Business and Supplier Policies on Labor Trafficking and Child Labor, an important source of substantive norms in the human rights context. ${ }^{43}$ These Policies implement certain principles (Principles) on supply chain risks involving labor trafficking and child labor. ${ }^{44}$

The Model Terms would have suppliers under an SCA represent and warrant that they-and their "Representatives" (defined below)have complied with the substantive KSR terms (which appear in what the Working Group would call "Schedule P," for "principles"), and

41. Jan B. Heide, Alok Kumar \& Kenneth H. Wathnes, Concurrent Sourcing, Governance Mechanisms, and Performance Outcomes in Industrial Value Chains, 35 STRATEgic MGMT. J. 1164, 1166-67 (2014).

42. David V. Snyder \& Susan A. Maslow, Human Rights Protections in International Supply Chains-Protecting Workers and Managing Company Risk, 73 BUS. LAW. 1093, 1096-105 (2018) (setting forth model clauses to be inserted into supply contracts, purchase orders, or similar documents involving the sale of goods).

43. See ABA Model Business and Supplier Policies on Labor Trafficking and Child Labor, AM. http://www.americanbar.org/groups/business_law/initiatives_awards/child_labor.html [https://perma.cc/E4FT-2ZFB].

44. For a discussion of the Principles, see E. Christopher Johnson Jr., Business Lawyers Are in a Unique Position to Help Their Clients Identify Supply-Chain Risks Involving Labor Trafficking and Child Labor, 70 Bus. LAw. 1083 (2015). 
agree that compliance with Schedule $\mathrm{P}$ is a "material" term of the contract. ${ }^{45}$ The Model Terms define a "Representative" as potentially including "shareholders/partners, officers, directors, employees . . . [and] agents of Supplier and all intermediaries, subcontractors, consultants and any other person providing staffing for Goods or services required by this Agreement [on behalf of Supplier]." 46 The Model Terms would also require the supplier to have policies implementing the standards, themselves ${ }^{47}$ and to notify the buyer of any violations of the foregoing. ${ }^{48}$ The goal appears to be to assure that the substantive human rights norms that the buyer wants the seller to honor flow through the seller to all those in some direct or indirect relationship with the seller, including its suppliers, sub-suppliers, and so on.

Monitoring for violations of KSR terms will be difficult, and so parties may leave the task to professionals. ${ }^{49}$ Starbucks, for example, claims that ninety-nine percent of their coffee is ethically sourced..$^{50}$ To assure this, Starbucks' Coffee and Farmer Equity (C.A.F.E.) Practices have been implemented with the help of Conservation International and SCS Global Services. ${ }^{51}$ Under the C.A.F.E. Practices, farms and mills are audited by third parties using a scorecard that tracks wages and benefits, work hours, child/forced labor, access to housing/water/sanitary facilities, and so on. ${ }^{52}$ Companies such as SGS

45. Snyder \& Maslow, supra note 42, at 1099 ("It is a material term of this Agreement that Supplier and Representatives shall strictly comply with Schedule P.").

46. Id. at 1097 (referencing $\S 1.1$ ).

47. Id. at 1098 (referencing $\S 1.3$ ).

48. Id

49. Jodi L. Short, Michael W. Toffel \& Andrea R. Hugill, Monitoring Global Supply Chains, 37 STRATEgIC MGMT. J. 1878, 1879 (2016) (observing that "private supply chain monitoring has been adopted by thousands of prominent multinational corporations (MNCs), including all U.S. Fortune 500 companies").

50. See Committed to $100 \%$ Ethically Sourced, STARBUCKs, https://www.starbucks.com/responsibility/community/farmer-support/farmer-loanprograms [https://perma.cc/PL5T-V62S]. The C.A.F.E. Practices include guidelines concerning: quality of the coffee; transparency of economic transactions (e.g., "[s]uppliers must submit evidence of payments made throughout the coffee supply chain"); living conditions, including compliance with minimum wage requirements and prohibition of child and forced labor; and environmental issues such as water and energy conservation and waste reduction. Id.; see also Ethical Sourcing: Coffee, STARBUCKS, [https://perma.cc/LUY2-XARL].

51. See Starbucks C.A.F.E. Practices, SCS Global SERvs., https://www.scsglobalservices.com/services/starbucks-cafe-practices [https://perma.cc/V6FN-PPVZ].

52. Starbucks Coffee Company C.A.F.E. Practice Generic Scorecard (Dec. 2014), https://globalassets.starbucks.com/assets/4a67ce15e63b4ea18461ff65a540feb3.pdf [https://perma.cc/NPT7-QV5S]. 
International Certification services, ${ }^{53}$ DNV Det Norske Veritas, ${ }^{54}$ BVQI Bureau Veritas Quality International, ${ }^{55}$ Intertek Testing Services, ${ }^{56}$ and TUV Rheinland $\mathrm{Ltd}^{57}$ provide similar services.

But there will be significant practical and legal constraints on monitoring. The length and geographic distance of supply chains will make it difficult for monitors to gain real-time access to the work environments for more remote suppliers. Even when they can walk the factory floor, there is no guarantee that monitors will see the things that matter. In 2012, for example, over 200 workers died in a garment factory fire in Karachi, Pakistan only weeks after it had passed a safety inspection. ${ }^{58}$ There may also be factors internal to inspection teams that limit their effectiveness, including their composition and prior relationships among personnel. ${ }^{59}$ Moreover, parties up the supply chain may have legitimate competitive reasons, such as the protection of trade secrets, for resisting or limiting monitoring.

\section{REMEDY}

The legal force of any right to monitor, and indeed of substantive KSR terms generally, depends on the remedies available for breach. But, as with monitoring, there will be significant constraints on the ability to use ordinary remedies. While the Model Terms would attempt to contract around some of these limitations, it is not clear how effective contracting around background law can be in this context.

53. See SCS GLOBAL SERVS., supra note 51 (noting that an organization can certify to SA 8000 with an SGS audit).

54. Corporate Sustainability, DNV GL, https://www.dnvgl.com/about/ sustainability (noting that DNVL GL's businesses are certified according to ISO 9001 standard and work toward sustainable development goals).

55. See Social Responsibility and Responsible Sourcing Certification, BUREAU VERITAS, https://certification.bureauveritas.com/social-responsibility-and-responsiblesourcing-certification [https://perma.cc/6H9E-5T6K] (noting that Bureau Veritas is an independent organization that performs social responsibility audits).

56. See Certification, INTERTEK, http://www.intertek.com/certification [https://perma.cc/5RAY-3GVE] (advertising that Intertek offers certification programs for environmental and social accountability compliance).

57. See Certification and Auditing Services for Social Responsibility, TÜV RHEINLAND, https://www.tuv.com/usa/en/social-responsibility.html [https://perma.cc/YCU2-S3GV] (offering services to assess and certify companies' compliance with social responsibility and fair working conditions).

58. Declan Walsh \& Steven Greenhouse, Certified Safe, a Factory in Karachi Still Quickly Burned, N.Y. TrMes (Dec. 7, 2012), https://www.nytimes.com/2012/12/08/world/asia/pakistan-factory-fire-shows-flaws-inmonitoring.html [https://perma.cc/JMX2-KAWP].

59. Short et al., supra note 49. 


\section{a. Expectation}

The default remedy for breach of contract under U.S. law is "expectation" damages: put the aggrieved party in the economic position she reasonably expected in performance. ${ }^{60}$ In basic form, this is a dollar value measured as the difference between what was promised and what was delivered. So, if seller (S) failed to deliver to buyer (B) promised widgets at a price of $\$ 10 /$ widget, $B$ would get the difference between $\$ 10 /$ widget and the higher price it had to pay for substitute widgets.

This obviously glosses over a great deal of nuance, but the question is simple: what would expectation look like to remedy the breach of a substantive KSR term? ${ }^{61}$ In the case of many KSR promises, there is a plausible argument that the conventional expectation measure would be zero because the breach may not have affected the economic value of the promisor's commercial promise. If, for example, GM purchased components that conformed to the contract except with respect to the labor conditions of their production, its seller may argue that the breach has caused no cognizable damage. That is, the breaching promisor would argue that there is no difference in value that is economically compensable under baseline rules. ${ }^{62}$ Indeed, the promisor may assert that it was able to perform on the economics only (or largely) because it breached the KSR term by, for example, underpaying its workforce. It would, in this sense, argue that breach of the KSR term was "efficient." 63

60. REstatement (SECOND) CONTRACTS $\$ 347$ (AM. LAW. INST. 1981); U.C.C. § 1-305 (AM. LAW INST. \& UNIF. LAw, COMM'N 2014); see also Melvin A. Eisenberg \& Brett $\mathrm{H}$. McDonnell, Expectation Damages and the Theory of Overreliance, 54 HASTINGS L.J. 1335, 1336 (2003) ("The basic remedy for breach of a bargain contract is the expectation measure of damages, which puts the injured party where she would have been if the contract had been performed.").

61. Breach of monitoring or other procedural terms might be addressed by specific performance, though for reasons discussed below, that too will be problematic.

62. Section 2-712 of the Uniform Commercial Code provides that " $[\mathrm{t}] \mathrm{he}$ buyer may recover from the seller as damages the difference between the cost of cover and the contract price together with any incidental or consequential damages." U.C.C. $\S$ 2-712 (AM. LAW INST. \& UNIF. LAW COMM'N 2014). Section 2-713 gives the aggrieved buyer "the difference between the market price at the time when the buyer learned of the breach and the contract price together with any incidental and consequential damages . . ." Id. § 2-713. As discussed below, the buyer may have an argument that the breach caused consequential damages, although it is a difficult argument to make absent the specification contemplated by the Model Terms. Id. $\S \S 2$ 712 to $2-713$.

63. The theory of efficient breach holds:

[B]reach will occur where the breaching party anticipates that paying compensation and allocating his resources to alternative uses will make him "better off" than performing his obligation. As long as the compensation 


\section{b. Consequential Damages-Reputational Harm}

If the goods or services conform to the contract, the harm from breach may be to the promisee's reputation (if the breach is made public). Thus, if a promisee like Nike or Wal-Mart learns the hard way that suppliers in its chain engaged in problematic labor practices, the harm would not be that breach necessarily impaired the value of the goods themselves, but instead, that breach damaged the brand. ${ }^{64}$

In theory, courts may recognize claims for reputational damage as a consequence of a breach of contract-but they usually don't like to do so because, like all claims of consequential damage, judges worry that the harm may not have been within the contemplation of the parties and may be difficult to quantify. ${ }^{65}$ In Redgrave $v$. Boston Symphony Orchestra ${ }^{66}$ probably the leading case on the subject, the First Circuit Court of Appeals recognized that actress Vanessa Redgrave could in principle recover from the Boston Symphony Orchestra when it breached a performance agreement with her due to her controversial positions on the State of Israel. But, she was unable to show that most of the damages she sought were in fact due to the breach. ${ }^{67}$

Applied to a corporate plaintiff, questions of reputational harm from breach are even more difficult. Notorious incidents like the Takata airbag recall may affect car-makers' reputations in some way, but the effect will be diffuse and difficult to price.$^{68} \mathrm{~A}$ corporation may have a brand and good will that derive from and reflect its reputation, but

adequately mirrors the value of performance, this damage rule is "efficient." It induces a result superior to performance, since one party receives the same benefits as performance while the other is able to do even better.

Charles J. Goetz \& Robert E. Scott, Liquidated Damages, Penalties and the Just Compensation Principle: Some Notes on an Enforcement Model and a Theory of Efficient Breach, 77 Colum. L. REv. 554, 558 (1977); see also Thomas Ulen, The Efficiency of Specific Performance: Toward a Unified Theory of Contract Remedies, 83 MICH. L. REV. 341, 342 (1984) (explaining that a breach is said to be "efficient" where "at least one party can be made better off, without making anyone worse off . . ."). The argument would be that, absent reputational harm, the promisee is no worse off due to breach of the KSR term, and the promisor is better off because performing the KSR term would have increased the promisor's costs.

64. Kishanthi Parella, Reputational Regulation, 67 DUKE L.J. 907, 910 (2018) (discussing reputational effects of litigation).

65. Redgrave v. Boston Symphony Orchestra, 855 F.2d 888, 892-93 (1st Cir. 1988) (citing Skagway City School Bd. v. Davis, 543 P.2d 218, 225 (Alaska 1975)).

66. 855 F.2d 888 (1st Cir. 1988).

67. Id. at 897 (upholding only $\$ 12,000$ of $\$ 100,000$ jury award because Redgrave had not "presented sufficient evidence to prove that her financial difficulties were caused by the BSO cancellation").

68. See Do Mass Recalls Impact the Car Manufacturers' Reputation?, REPUTATION INST., https://www.reputationinstitute.com/research/do-mass-recallsimpact-car-manufacturer-reputation [https://perma.cc/9MCQ-Q6RZ]. 
harm to the corporation's reputation only indirectly affects real people, such as its shareholders, creditors, and so on. ${ }^{69}$ Courts worry about awarding damages that are "speculative." companies, as for Vanessa Redgrave, market value can be affected by many factors having nothing to do with a contract party's breach. ${ }^{71}$

Parties can solve part of the problem here by expressly contracting for consequential damages. ${ }^{72}$ In ordinary contracts, doing so may reduce the risk of over-investment by one party that invites opportunistic defection by the other. ${ }^{73}$ Here, a multinational buyer that

69. See Claire A. Hill, Marshalling Reputation to Minimize Problematic Business Conduct, 99 B.U. L. REv. 1193, 1196 (2019) ("Corporations are assumed to want a good reputation if for no other reason than an instrumental one, to do things they would not otherwise do, and to refrain from doing things they would otherwise do, in order to obtain it."); see also J.B. Heaton, What Injures a Corporation? Toward Better Understanding Corporate Personality, 73 Bus. LAw. 1031, 1031 (2018) (noting that a "corporation's loss of asset value or profits through another's wrongful action is a pass-through event that we can trace, dollar-for-dollar, to its impact on shareholders, creditors, employees, and others, such as people who own houses in the community around the corporation's headquarters or taxing governments and the consumers of functions for which those taxes provide funding").

70. "Above all, it is well-settled that an award of damages cannot be speculative in nature. 'Damages may only be allowed when there is probative evidence of the amount of damages. And while, where damages cannot be precisely proved, proof upon a reasonable basis is sufficient, no damages may be awarded on a purely speculative basis." "Hangzhou Silk Imp. \& Exp. Corp. v. P.C.B. Int'l Indus., Inc., No. 00 Civ. 6344 (RLC), 2002 WL 2031591, at *7 (S.D.N.Y. Sept. 5, 2002) (quoting Wayne Cty. Vinegar \& Cider Corp. v. Schorr's Famous Pickled Prods., Inc., 460 N.Y.S.2d 209, 217-18 (1983)); see also Toltec Fabrics, Inc. v. August Inc., 29 F.3d 778, 780 (2d Cir. 1994). Marisa Anne Pagnattaro \& Ellen R. Peirce, From China to Your Plate: An Analysis of New Regulatory Efforts and Stakeholder Responsibility to Ensure Food Safety, 42 GEO. WASH. INT'L L. REN. 1, 3-4 (2010) ( "[C]orporations that subcontract with suppliers from China for food and drug manufacturing also have concerns on a number of fronts. First, tainted foods harm their consumers. Second, once the public becomes aware of the source of consumer harm, the corporations will suffer consequential harm to their reputations.").

71. Redgrave, 855 F.2d at 896.

72. Clayton P. Gillette, Tacit Agreement and Relationship-Specific Investment, 88 N.Y.U. L. REV. 128, 131 (2013) ("Notwithstanding the claims of ubiquitous exclusion, some sophisticated commercial parties do not disclaim consequential damages. Contracts without disclaimers fall into two categories: (1) those in which the parties are silent about consequential damages and (2) those in which the parties restate the default.").

73. Id. at 132-33. Expressly including consequential damages-

can diminish the threat inherent in transactions that require one party to make a relationship-specific investment-an investment that, once made, cannot readily be utilized in an alternative transaction-before the other party is obligated to invest in the same transaction. In transactions with those characteristics, the investing party risks exploitation by its counterparty after the initial investment is made. I suggest that a pledge to pay consequential lost profits in the event of breach reduces the threat of holdup. As a result, in a discrete set of circumstances the promise has value 
sources from different companies around the world may experience high switching costs in the event of breach by sellers, for example by having to retool its production and renegotiate with other suppliers.

Not surprisingly, it appears that the advice in this context is to "restate the default," and to require the supplier to pay consequential damages ${ }^{74}$ The Model Terms advise supply chain buyers to do the same for breach of KSR terms. ${ }^{75}$ The principal advantage of specifying that breach of the KSR term causes consequential damage will be that it overcomes one of the two main legal hurdles to recovering these damages, that they were in the contemplation of the parties. However, doing so does not necessarily solve a second problem, which is that courts may still worry that claims of reputational harm are hard to quantify.

\section{c. Liquidated Damages and Indemnification}

The obvious response, and one that the Model Terms embrace, is to liquidate damages. ${ }^{76}$ The UCC and the common law articulate slightly different tests for whether a liquidated damages clause would be enforceable, but both essentially try to uphold "reasonable" amounts, and to deter "penal[ties]." the liquidation is a penalty by reference to its capacity to predict ex ante, or to reflect ex post, actual harm. If the liquidation diverges materially from actual damage, it is more likely to be a penalty. If there

in excess of its cost, including the cost otherwise inherent in assigning consequential damages to the party less able to avoid them. While a pledge of lost profits in the event of breach is not the exclusive response to this holdup problem, it is a plausible, and perhaps superior, means of avoiding it.

Id. (internal footnote omitted).

74. Gillette, supra note 72; see also AlAN S. GutTERMAN, Business TRANSACTIONS Solutions § 279:62 (2019) ("Seller shall be liable and shall defend, indemnify, and hold Buyer harmless for any claims or damages, direct or indirect, incidental or consequential, arising from or occasioned by any change or modification to the Product that has not been approved by Buyer, notwithstanding any other limitations or waivers of liability, warranty, or remedy contained in this Agreement.").

75. See Snyder \& Maslow, supra note 42 , at $1102-03$ (\$\$ 5.3, 5.4).

76. The Model Terms provide:

Supplier acknowledges that it may be difficult for Buyer to fix actual damages or injury to its business, prospects and reputation with respect to Goods produced in violation of Schedule $\mathrm{P}$ or associated with a company that has violated Schedule $\mathrm{P}$, and the parties have therefore agreed to liquidated damages in an amount calculated as follows:

Id. at $1103(\S 5.4)$.

77. U.C.C $§ 2-718(1)$ (AM. LAW INST. 2017); REsTATEMENT (SECOND) OF CONTRACTS $\$ 356$ (AM. LAW INST. 1981). 
are significant disputes about the amount of the damage, or how to value it, a liquidation may provide little guidance for a court. ${ }^{78}$

More effective may be a right of indemnification for expenses incurred by the buyer seeking to remediate the breach of a KSR term. So, for example, the Model Terms provide that the seller must indemnify the buyer for actual loss resulting from breach of a KSR promise. ${ }^{79}$ Indemnification, unlike a liquidation of damages, tends to award to the indemnitee (e.g., the KSR promisee) actual expenses incurred pursuant to a formula usually negotiated by the parties. While liquidated damages and indemnification are both forms of recourse to a breaching promisor, the latter tends to be less problematic for courts, because they need not speculate on the amount of damage-they need only determine whether the expense was within the indemnification formula. While indemnification may not directly remedy reputational harm, it may help indirectly by requiring the promisor to pick up the tab for costs actually incurred by the promisee due to breach of the KSR term, such as by hiring communications consultants who provide damage control.

\section{d. Specific performance}

The parties and courts may avoid the problem of quantifying damages for breach of a substantive KSR term by resorting to specific performance or an injunction. Thus, the Model Terms provide that remedies for breach of KSR terms may include an injunction enforcing the term; B's right to require $S$ to remove problematic employees or "Representatives" of S; and B's right to require $S$ to terminate contracts with sub-suppliers. ${ }^{80}$

78. The court may, for example, decide that by the time of adjudication, there is no harm to the buyer because the reputational damage cannot be undone or quantified.

79. The ABA Model Terms, for example, provide:

[The Supplier indemnifies the Buyer for] any and all losses, damages, liabilities, deficiencies, claims, actions, judgments, settlements, interest, penalties, fines, costs or expenses of whatever kind, including, without limitation, the cost of storage, return, or destruction of Goods, the difference in cost between Buyer's purchase of Supplier's Goods and replacement Goods, reasonable attorneys' fees, audit fees, and the costs of enforcing any right under this Agreement or applicable law, in each case, that arise out of the violation of Schedule P by Supplier or any of its Representatives. This Section shall apply, without limitation, regardless of whether claimants are contractual counterparties, investors, or any other person, entity or governmental unit whatsoever.

Snyder \& Maslow, supra note 42 , at 1104-05 (§ 5.6).

80. Id. at 1101-03 (\$§ 5.1-5.4). 
But under U.S. law, specific performance is an "exceptional remedy." ${ }^{81}$ U.S. courts will grant it where the aggrieved party can show that goods are "unique" or in "other proper circumstances." 82 But, an order of specific performance of KSR terms may involve matters of governance or value-choice, which can be problematic for courts. Ordinarily, for example, personal services contracts are not enforceable by way of specific performance. ${ }^{83}$ So, if a movie production company breaches a diversity promise in an inclusion rider, how would a court decide which actors to require the promisor to hire?

Courts seem no more inclined to grant specific relief for claims of reputational harm than to award money damages. ${ }^{84}$ While a court can back up such an order with contempt powers, ${ }^{85}$ it is unclear how effective those powers are, especially against defendants who may be in foreign nations. In any case, if the harm to B is reputational, isn't B's better solution to buy from someone else-meaning to rescind the contract?

\section{e. Rescission}

Rescission may seem like an appealing approach, because it enables the promisee to wash its hands of the offending promisor. ${ }^{86}$ Strictly speaking, rescission is not a contract remedy, but instead an equitable response to disappointed expectations in a variety of contexts. Unlike expectation or specific performance, rescission is not forward

81. Melvin A. Eisenberg, Actual and Virtual Specific Performance, the Theory of Efficient Breach, and the Indifference Principle in Contract Law, 93 CALIF. L. REV. 975, 1016 (2005); see, e.g., RESTATEMENT (SECOND) OF CONTRACTS $\$ \$ 357$, 359-60, 366-67 (AM. LAW INST. 1981).

82. See Andrea G. Nadel, Annotation, Specific Performance of Sale of Goods Under UCC § 2-716, 26 A.L.R. 4th 294, 298 (1983). For critical assessment of court's treatment of requests for specific performance, see Douglas Laycock, The Death of the Irreparable Injury Rule, 103 HARV. L. REV. 687, 692 (1990).

83. See Lipson, supra note 7, at 1763-64.

84. Bennington Foods $L L C$ v. St. Croix Renaissance, Grp., LLP, 528 F.3d 176, 178-79 (3d Cir. 2008) ("[A] plaintiff in a breach of contract case cannot convert monetary harm into irreparable harm simply by claiming that the breach of contract has prevented it from performing contracts with others and that this subsequent failure to perform will harm the plaintiff's reputation.").

85. Gene R. Shreve, Federal Injunctions and the Public Interest, 51 Geo. WASH, L. REV. 382, 389 (1983) (discussing the "specter of civil and criminal contempt" for disobeying a federal injunction).

86. The Restatement (Third) of Restitution and Unjust Enrichment provides that a promisee may rescind a contract in the event of a "material breach" by the promisor. RESTATEMENT (THIRD) OF RESTITUTION AND UNJUST ENRICHMENT § 37 (AM. LAW INST. 2011). 
looking, but instead seeks to "put the parties in the same position as if the contract had never existed, the so-called status quo ante." ${ }^{87}$

But rescission also presents at least two problems. First, analysts worry that rescission undercuts the performance-enforcing goals of expectation, by making it too easy to walk away. ${ }^{88}$ If $\mathrm{S}$ knows that $\mathrm{B}$ can always escape at any time, it will take greater precautions, and invest less in the performance, than if it believes B to be bound to some relatively predictable commitment. Nor does restitution (which may accompany rescission) assure the promisee that it can recover sunk costs. It may be entitled to compensation for benefits conferred on the promisor, but not for relationship-specific investments it made in reliance on the contract. In principle, a buyer cannot recover consequential damages if it rescinds the contract. ${ }^{89}$

Second, rescission would, as Holmes colorfully observed, "annihilate[ the contract." ${ }^{90}$ Although it is not entirely clear what this means, it may force the promisee to relinquish the benefit of other promises in the contract. This may be a serious problem for breach of KSR terms in multinational supply chain agreements because it may impair flow-through rights to indemnification or liquidated damages. ${ }^{91}$

\section{The Problem of Un(der)-enforceability_ "Interior" Remedies.}

There is nothing inherently remarkable about traditional contract terms or remedies that are un- or under-enforceable. Victor Goldberg has argued that the famous contract between General Motors and Fisher Body was probably not legally enforceable. ${ }^{92}$ Lisa Bernstein has found much the same to be true in her recent study of original equipment

87. Richard R.W. Brooks \& Alexander Stremitzer, Remedies on and off Contract, 120 YALE L.J. 690, 692 (2011).

88. Id. at 693 (observing that courts worry that "easy availability of rescission followed by restitution, has been a source of great anxiety among legal authorities, who see it as a threat to commercial order and other normative values").

89. Historically, courts appear to have taken the view that consequential damages were not available to a party that sought rescission. See, e.g., Rennie v. Pierce Cards, Ltd., 65 A.D.2d 527, 528, 409 N.Y.S.2d 395, 396 (1978) ("[P]laintiff, having elected to rescind, cannot recover lost profits . . . ."). More recent cases appear to be more tolerant of providing both remedies. See PHL Variable Ins. Co. v. Clifton Wright Family Ins. Tr., No. 09CV2344 BTM (POR), 2010 WL 1445186, at *2 (S.D. Cal. Apr. 12, 2010) ("Courts have awarded consequential damages to the aggrieved party following rescission of a contract in various contexts.").

90. Ballou v. Billings, 136 Mass. 307, 309 (1884). 1969).

91. Cf. Barrera v. State Farm Mut. Auto. Ins. Co., 456 P.2d 674 (Cal.

92. See Victor P. Goldberg, Lawyers Asleep at the Wheel? The GM-Fisher Body Contract, 17 INDUS. \& CORP. ChANGE 1071, 1076-80 (2008). 
manufacturers' contracts. ${ }^{93}$ Indeed, as discussed in Part III, relational contract theory can be seen as an extended effort to explain why parties use contracts that may have little direct legal force.

In addition to doctrinal limitations noted above, the parties themselves may deliberately use procedures that leave the substantive terms under-enforceable. Consider, for example, Hewlett Packard's Code of Conduct for suppliers (HP Code), which sounds like it means business about its substantive social responsibility expectations. HP suppliers must meet or exceed local legal standards. ${ }^{94}$ "Where the HP Code and national or local laws have requirements for the same subject matter, Suppliers shall meet the more stringent requirements. ${ }^{\text {95 }}$ It then offers elaborate statements of these "requirements" in five areas, labor, health and safety, environmental, ethics and management systems. ${ }^{96}$

Yet, it is not clear how much an HP supplier is actually agreeing to do. Although HP's website says that the HP Code is "part of any contract with an HP legal entity that obligates a Supplier to comply with HP's sustainability requirements or policies," 97 it also appears that those requirements are more aspirational and iterative than substantive. ${ }^{98}$ Thus, HP suppliers apparently agree to a "Supplier Social and Environmental Responsibility Agreement." $" 99$ But, this agreement does not require compliance with the substance of the HP Code. Rather, it requires an HP supplier to "confirm[ that it has read" the Code; ${ }^{100}$ that it will "identify $\square$ areas of its operations that do not

93. Bernstein, supra note 15 , at 562 (observing that "[a]lthough the contracts used to consummate these transactions are long and detailed, they are not designed to create incentives for performance and breach primarily through the prospect of courtimposed monetary damages"). 2018),

94. Hewlett-Packard, HP Supplier Code of Conduct, Version 6.0 (Aug. 21, http://h20195.www2.hp.com/V2/getpdf.aspx/c04797684 [https://perma.cc/AJL6-S5FB]. For example, the HP Code provides that an HP supplier agrees that "[f]orced, bonded (including debt bonded) or indentured labor; involuntary or exploitative prison labor; or slavery or trafficking of persons shall not be used. . . . All work must be voluntary, and workers shall be free to leave work at any time or terminate their employment." Id.

95. Id.

96. Id.

97. Sustainable Impact, Supplier Sustainability Requirements, HEwLETTPACKARD, https://www8.hp.com/us/en/hp-information/globalcitizenship/society/supplier-ser-

requirements.html?jumpid = in_r138_us/en/corp/supply_chain/in-page-nav/supplier-serrequirements.

98. HeWletT-PACKARD, Supplier Social \& Environmental Responsibility Agreement, supra note 4. It should also be obvious that HP may not, in fact, use these terms in practice, even though it publishes them on its website. Those decisions will be confidential to HP and its contract counterparts.

99. Id.

100. Id. (“Supplier confirms that it has read HP Supplier Code of Conduct (also known as the HP Electronic Industry Code of Conduct or HP EICC Code of 
conform" to the Code; ${ }^{101}$ and that it will submit a report about "progress" toward the Code, if HP asks for one, and provide supporting records. ${ }^{102}$

In many cases, KSR regimes contain what Lisa Bernstein has characterized as "interior" remedies-systems within the contract to incentivize compliance without resorting to conventional remedies or termination. ${ }^{103}$ If, for example, Starbucks discovers a violation of its supplier code of conduct, it states that it will first work with the supplier to "develop and implement a corrective action plan." 104 If that does not work, the supplier may be considered in material breach which "may result in cancellation of any current orders and/or termination of Starbucks contractual relationship with the supplier." ${ }^{105}$ In addition, gross violations and illegal activities are grounds for immediate termination of the relationship. ${ }^{106}$

A cynical view would be that terms like those used by HP and Starbucks impose little in the way of meaningful legal obligations on either the multinational buyers or their local suppliers. Presumably, HP or Starbucks could ask for specific performance of the promises to "read" the standards in question or to develop a corrective action plan for their breach, but so what? With or without breach, it is likely that neither buyer has fixed, long-term obligations to purchase from their suppliers. So, HP or Starbucks can probably always walk away. They may suffer switching costs, but that would simply suggest that the contract with its KSR terms was ill-advised or poorly priced. Or, it may suggest that these buyers have limited incentives to enforce the substantive KSR terms. In either case, promises to achieve social responsibility will often be policed by remedies internal to the contract

Conduct) and HP's General Specification for the Environment and agrees with its statement of requirements.").

101. Id. ("Supplier will be responsible for identifying any areas of its operations that do not conform to HP's Supplier Code of Conduct and HP's General Specification for the Environment and for implementing and monitoring improvement programs designed to achieve HP Supplier Code of Conduct and HP's General Specification for the Environment.").

102. Id. ("Upon request by HP, Supplier will submit a report to HP describing actions taken and progress made by Supplier to meet the requirements ....").

103. Bernstein, supra note 15 , at 571 (observing that most master supply agreements she studied "contain a self-help damage remedy that enables buyers to obtain some monetary compensation without ending a relationship," which she characterizes as "interior remedies").

104. Starbucks, Starbucks Disclosure in Compliance with California Transparency in Supply Chains Act of 2010 (SB 657), https://globalassets.starbucks.com/assets/2994ceff517a44aca17df6f1237c4c13.pdf [https://perma.cc/FJP9-G93H].

105. Id.

106. Id. 
and the parties' relationship, and not by the legal system in any conventional sense.

\section{WHY KSR?}

If KSR terms will not behave doctrinally or practically like ordinary contract terms, what drives parties to use them? This part argues that KSR terms are responses to normative pressures that take the form of, among other things, "soft" law, positive public law, litigation risk, and reputational sanctions. KSR terms respond to these pressures because traditional social and legal structures, such as community or the vertically integrated corporation, have devolved, flattened into a state that may be characterized as "vertical deconstruction."

\section{A. Normative Pressure}

If KSR terms respond to normative pressure, we might first ask: what norms are we talking about and where do they come from?

\section{SOFT LAW: NORM GENERATION REGIMES}

The substantive norms that KSR may pursue come from norm generation regimes such as government, non-governmental organizations, quasi-governmental organizations, certification organizations, not-for-profits, and the like, who make it their business to articulate social norms that they hope others will internalize and follow. ${ }^{107}$ Although these norms often are not and do not purport to be law, they form a critical early link in the chain by which KSR seeks to deliver social change on a retail basis.

Perhaps the most high-profile and compelling examples involve human rights in the supply chain and climate change. NGOs such as the United Nations, the OECD, Amnesty International, and the American Bar Association, among many others, have articulated various norms

107. Backer, supra note 29 , at 1756 ("In a sense, the shaping of norms and social preferences in behavior is its own industry-for the production of culture."). Although there is debate about what constitutes a "norm," Posner has the following:

A norm is a social rule that does not depend on government for either promulgation or enforcement. . . . Laws are promulgated by public institutions, such as legislatures, regulatory agencies, and courts, after welldefined deliberative procedures, and are enforced by the police power of the state, which ultimately means by threat of violence. Norms are not necessarily promulgated at all. If they are, it is not by the state.

Richard A. Posner \& Eric B. Rasmusen, Creating and Enforcing Norms, with Special Reference to Sanctions, 19 INT'L REV. L. \& ECON. 369, 369-70 (1999). 
and principles that would seek to reduce or ameliorate these sorts of harms. ${ }^{108}$ The Ruggie Principles are perhaps the best known examples involving multinational corporations' effect on human rights, and are the product of a United Nations project. ${ }^{109}$ The Model Terms discussed above emanate from ABA Principles on human rights in global trade. ${ }^{110}$ To an important extent these organizations form part of "civil society," the "aggregate of non-governmental organizations and institutions that manifest interests and will of citizens."111

108. Halliday offers a laundry list of some of the key players:

[T] he paramount institutions of global normmaking: international courts, such as the ICC, tribunals for war crimes, the World Trade Organization's (WTO's) appellate panels for adjudication of trade disputes among nations, or the World Health Organization's (WHO's) guidelines on health care; international financial institutions (IFIs) whose Washington- or London- or Manila-based organizations forge regional and global financial architectures out of legal principles and rules; world governance bodies that range from the United Nations (UN) Security Council's deliberations on relations among states to the UN forums for monitoring abuses against women and children and UN entities that promulgate norms for health, climate change, labor and trade; clubs of nations, such as the G-7, G-20, and OECD, which propose frameworks of regulatory norms for economic behavior; international professional associations, whose programmatic aspirations reach to accounting, legal, and scientific standards; and networks of international nongovernmental organizations (INGOs) and business INGOs (BINGOs) whose agendas traverse the terrain of private and public interests.

Terence C. Halliday, Recursivity of Global Normmaking: A Sociolegal Agenda, 5 ANN. REV. L. \& Soc. SCI. 263, 264 (2009).

109. See U.N. Office of the High Commissioner, Guiding Principles on Business and Human Rights: Implementing the United Nations "Protect, Respect and Remedy" Framework, U.N. Doc. HR/PUB/11/04 (June 16, 2011), http://www.ohchr.org/Documents/Publications/GuidingPrinciplesBusinessHR_EN.pdf [https://perma.cc/92A6-WE8U]; see also Human Rights Council, Report of the Special Representative of the Secretary-General on the Issue of Human Rights and Transnational Corporations and Other Business Enterprises, John Ruggie, U.N. Doc. A/HRC/17/31 (Mar. 21, 2011), https://undocs.org/en/A/HRC/17/31. For recent guidance on how companies can use them, see John F. Sherman, III, Wise Counselling on Global Supply Chains: The IBA Practical Guide on Business and Human Rights for Business Lawyers, 5 Bus. \& HuM. RTS. Rev. 22 (2017).

110. See Snyder \& Maslow, supra note 42, at 1093 (explaining that Model Terms are "part of a larger effort to achieve widespread implementation of the ABA Model Business and Supplier Principles on Labor Trafficking and Child Labor"); see, e.g., ABA Model Business and Supplier Principles on Labor Trafficking and Child Labor, supra note 43. For a detailed discussion, see Johnson Jr., supra note 44.

111. See Catherine Albiston, Democracy, Civil Society, and Public Interest Law, 2018 Wis. L. Rev. 187, 188 (quoting Civil Society, DiCTIONARY.COM, https://web.archive.org/web/20180310221808/http://www.dictionary.com/browse/civil -society? $\mathrm{r}=66$ ). 
There is little doubt that these organizations generate and articulate norms that have tremendous impact in society. ${ }^{112}$ Sometimes dismissed as producers of "soft law," 113 these organizations nevertheless have resources, expertise, and a visibility that enable them to persuade in cases where conventional state power is not likely to be a complete solution. ${ }^{114}$

There are, however, important limits to the power of norm generation regimes. They are vulnerable to Austin's critique that, lacking the sovereign's power of violence, their utterances cannot have the force of law. ${ }^{115}$ To the extent they do have influence, some worry that they may be undemocratic, reflecting the interests of the elites who run them or-worse-their financial benefactors, often the nation-states whose policies permit or create normatively problematic conditions in the first place. While persuasive and important, norm generation regimes cannot, by themselves, solve the sorts of normative problems that motivate their action. KSR may be seen as a part of the solution.

\section{HARD LAW}

"Hard" or positive law also plays an important role in driving parties to use KSR terms. In some cases, the law will be substantive in

112. See Hilary Charlesworth, The Unbearable Lightness of Customary International Law, 92 ASIL PROC. 44, 44 (1998) (citing Isabelle Gunning, Modernizing Customary International Law: The Challenge of Human Rights, 31 VA. J. INT'L L. 211 (1991)) ("[I]n the area of human rights, the activities of nongovernmental organizations (NGOs) should be regarded as constituting relevant practice in the generation of customary norms.").

113. Mashaw has argued that "soft-law" is constituted by "social accountability regimes" that may be "infinitely negotiable, continuously revisable, often unspoken; oscillating between deep respect for individual choices and relentless social pressure to conform to group norms." Jerry L. Mashaw, Accountability and Institutional Design: Some Thoughts on the Grammar of Governance, in PUBLIC AcCountaBiLITY 115, 120-25 (Michael W. Dowdle ed., 2006).

114. For discussions of soft law in international law, see Anne-Marie Slaughter et al., International Law and International Relations Theory: A New Generation of Interdisciplinary Scholarship, 92 AM. J. INT'L L. 367 (1998) (emphasizing the advantages of nonbinding soft law in the context of international governance and the generation of norms by supra-national institutions and their dissemination by nongovernmental organizations). See also Kathryn Libal \& Shareen Hertel, Paradoxes and Possibilities: Domestic Human Rights Policy in Context, in Human Rights IN THE UNited States: Beyond EXCEPTIONALISM 1, 12-14 (Shareen Hertel \& Kathryn Libal eds., 2011) (discussing how NGOs and grassroots organizations have generated a human rights "culture" in the United States in response to hostility to formal domestication of human rights norms).

115. John Austin, The Province of Jurisprudence Determined and the Uses OF THE STUDY OF JURISPRUDENCE 201 (Hackett Publishing Co. 1998) (1832) (arguing that international law is not law because it is set by general opinion, whereas positive law is set by a sovereign). 
the sense that it prescribes or proscribes conduct having social, economic, or environmental effects. In the United States, for example, laws on environmental protection have long been enforced indirectly via incorporation in commercial contracts such as loan or acquisition agreements. ${ }^{116}$ The underlying laws do not require that they become part of these contracts. Nevertheless, lenders and acquirers have long worried that a violation by a borrower or target would harm the interests of all parties. So, their contracts often require that the party potentially in violation (usually the borrower or target) represents in the contract that it is not, in fact, in violation. This has the indirect effect of either forcing compliance or disclosing noncompliance to the promisee. Vandenbergh characterizes this as a form of "private environmental governance," "[p]rivate-private interactions [that] generate many of the environmental requirements that affect corporate and household behavior, and ultimately environmental quality." ${ }^{117}$ One can imagine that Weinstein clauses may be more recent analogues in the context of sexual harassment, in that they may require a party to represent that it and its personnel have not violated positive legal proscriptions against work-place sexual misconduct. ${ }^{118}$

There is little doubt that positive law, usually in the form of legislation or regulation, plays a vital role in producing contract social responsibility. Yet, positive law suffers from three important limits in this context. First, if we are dealing with multinational supply chains, the extraterritorial reach of positive law is unclear, at best.

116. Vandenbergh, The Private Life of Public Law, supra note 9, at 2051-52 ("A sample of . . . credit agreements filed with the SEC suggests that . . . almost [seventy percent] of these include environmental provisions.").

117. Vandenbergh, Private Environmental Governance, supra note 9, at 133.

118. Other examples of positive law might include the Alien Tort Statute (ATS), the Foreign Corrupt Practices Act (FCPA) or even government's contractual power as an open-market purchaser. While these are all interesting and important, they suffer from various limits. The ATS has been narrowly construed. 28 U.S.C. $\S 1350$ (2018); see Kiobel v. Royal Dutch Petroleum Co., 569 U.S. 108, 124-25 (2013) (ruling that the presumption against extraterritoriality applies to the Alien Tort Statute unless the claims sufficiently touch and concern the territory of the United States). The FCPA prohibits bribes to a "foreign official" by a U.S. company, but says little about privateprivate behavior. Pub. L. No. 95-213, § 103-04, 91 Stat. 1494, 1495-97 (1977) (codified as amended in various sections of 15 U.S.C.); 15 U.S.C. $\$ 78 \mathrm{dd}-2$ (a) (1998). The Federal Acquisition Regulation seeks to limit human-trafficking by companies that sell to the U.S. government, but is subject to the vagaries of federal enforcement. FAR $\S \S 52.222-50$ (2006). See generally Lyndsey Conrad et al., Mandated Corporate Responsibility for Human Trafficking: New Federal Acquisition Regulation Steps up Supply Chain Accountability, 60 ST. LouIS U.L.J. 73 (2015). All doubtless play a role in KSR, though their specialized nature suggests that they should be considered in subsequent work. 
Multinationals are "stateless" for many purposes. ${ }^{119}$ While treaties may have the force of law and thereby incorporate and transplant legal rules, it is not clear whether (or how) they are enforceable. Sovereign nations may disagree about many things, but they usually agree that sovereignty is a foundational principle. Because corporations are not generally considered the subject of international law at all, it is not clear how positive law could regulate transnationals with globally dispersed subsidiaries and suppliers.

Second, positive law here often lacks substantive force. It could, for example, prohibit companies from engaging in the normatively problematic conduct, as is the case with environmental regulation. Instead, however, positive law often operates only indirectly, through forced disclosure. Thus, major steps toward reforming labor abuses in multinational supply chain agreements are the product of "naming and shaming" laws such as the -UK Modern Slavery Act. ${ }^{120}$ While reputational sanctions are important in this context, they are also an uncertain compliance mechanism.

Third, positive law may be subject to local resistance. This may be because the positive law fails to survive judicial scrutiny, as with DoddFrank's rules regarding disclosure of "conflict minerals" in the supply chain. ${ }^{121}$ Or, it may be because the government agency charged with

119. Hany H. Makhlouf, Multinational Corporations and Nation-States: Managing Shared-and Conflicts of Interest, 4 J. Soc. \& ADMIN. SCI. 139, 141 (2017) (noting that a multinational corporation resembles "a federation of different companies or semi-autonomous subsidiaries that are, at least, partially owned and controlled by a central unit").

120. UK Modern Slavery Act 2015, c. 30 (Eng.), http://www.legislation.gov.uk/ukpga/2015/30/contents/enacted [https://perma.cc/SCS7NFH7]. See also CAL. CIV. CODE § 1714.43 (West 2012); French Corporate Duty of Vigilance Law, Loi 2017-399 du 27 mars 2017 relative au devoir de vigilance des sociétés mères et des entreprises donneuses d'ordre [relating to the duty of vigilance of the parent companies and the companies giving order], JOURNAL OFFICIEL DE LA RÉPUBLIQUe FrançAise [J.O.] [OfFiCial GAZETTE OF FRANCE], Mar. 28, 2017; Directive 2014/95/EU, of the European Parliament and of the Council of 22 October 2014 Amending Directive 2013/34/EU as Regards Disclosure of Non-Financial and Diversity Information by Certain Large Undertakings and Groups, 2014 O.J. (L 330) 1.

121. An effort to combat slavery in the Democratic Republic of Congo required the Securities and Exchange Commission-the agency normally charged with policing America's financial markets-to issue regulations requiring firms using "conflict minerals" to investigate and disclose the origin of those minerals. DoddFrank Wall Street Reform and Consumer Protection Act, Pub. L. No. 111-203, § 1502, 124 Stat. 1376, 2213-18 (2010); see 15 U.S.C. § 78m(p)(1)(A) (2006). The Court of Appeals for the District of Columbia struck this in part on First Amendment grounds, although later reversed itself. See Nat'l Ass'n of Mfrs. v. SEC, 748 F.3d 359, 373 (D.C. Cir. 2014), aff'd on reh'g, 800 F.3d 518 (holding that disclosure requirements "violate the First Amendment to the extent the statute and rule require regulated entities to report to the Commission and to state on their website that any of 
enforcing the positive law chooses not to do so. ${ }^{122}$ More pragmatically, it may be because, in the case of multinational corporations, a host nation has no interest in cracking down on activities of the local subsidiary, even as those activities may offend norms native to the foreign parent corporation.

In short, positive law doubtless spurs contract social responsibility. But, like soft law, it is an incomplete explanation.

\section{LITIGATION RISK}

A third impetus for contract social responsibility reflects concerns about litigation risk arising from the social irresponsibility of contract counterparties. In 2013, for example, the Rana Plaza factory in Bangladesh collapsed, killing 1100 garment workers. ${ }^{123}$ This led to lawsuits against brands such as J.C. Penney and other multinationals whose clothes were apparently made under contract with the manufacturers there. ${ }^{124}$ Although the plaintiffs in that case failed to hold the multinational buyers liable, corporate violations of human rights have recently led to lawsuits arguing that these harms violated consumer protection law. ${ }^{125}$

their products have 'not been found to be "DRC conflict free"' "), and overruled by Am. Meat Inst. v. U.S. Dep't of Agric., 760 F.3d 18 (D.C. Cir. 2014).

122. Congress and President Trump subsequently rescinded Rule 13q-1, which effectively removes the requirement to report on conflict minerals. See H.R.J. Res. 41, 131 Stat. 9 (2017), https://www.congress.gov/bill/115th-congress/house-jointresolution/41/text [https://perma.cc/S944-WXFP] (providing for congressional disapproval of a rule submitted by the Securities and Exchange Commission relating to "Disclosure of Payments by Resource Extraction Issuers"). See also Laura D. Richman et al., Congress Nullifies SEC's Resource Extraction Issuer Payment Disclosure Rule, MAYER BROWN (Feb. 14, 2017), https://www.mayerbrown.com/congress-nullifies-secsresource-extraction-issuer-payment-disclosure-rule-02-14-2017/\#_ftn1

[https://perma.cc/L4J6-99KD].

123. Gillian B. White, What's Changed Since More than 1,110 People Died in Bangladesh's Factory Collapse?, The AtLantic: Business (May 3, 2017), https://www. theatlantic.com/business/archive/2017/05/rana-plaza-four-years-

later/525252/ [https://perma.cc/PA4V-TGRB].

124. Rahaman v. J.C. Penney Corp., No. N15C-07-174MMJ, 2016 WL 2616375, at *9 (Del. Super. May 4, 2016).

125. Rahaman, No. N15C-07-174MMJ, at *9; see also Andrew G. Barna, The Early Eight and the Future of Consumer Legal Activism to Fight Modern-Day Slavery in Corporate Supply Chains, 59 WM. \& MARY L. REV. 1449, 1453-54 (2018) (discussing consumer suits against Costco, Hershey, Nestlé USA, and Mars "for not disclosing human rights abuses within their supply chains").

The Rana Plaza disaster did lead to the creation of the Accord on Fire and Building Safety in Bangladesh. ACCORD ON FIRE AND BUILDING SAFETY IN BANGLADESH (May 13, 2013), http://www.laborrights.org/sites/default/files/publications-andresources/Accord_on_Fire_and_Building_Safety_in_Bangladesh_2013-05-13.pdf [https://perma.cc/EMW4-5DUZ]. Although that has been ${ }^{-}$characterized as an enforceable contract-and if so, would be an interesting example of KSR-it is in 
Litigation risk may be a strong concern for U.S. companies because the class-action lawsuit is so well-developed here. ${ }^{126}$ This would, in turn, drive the procedural contract terms described above, because they create or enhance the possibility of recourse in the event that a U.S. party must defend a class action lawsuit arising from breach of KSR terms.

While civil litigations against U.S. companies for serious normative failings across the supply chain have apparently not yet succeeded, there is a sense that it is only a matter of time. John Ruggie, for example, believes that while MNCs may not be prosecuted for crimes before the International Criminal Court, their "complicity" in those crimes, by turning a blind eye to misconduct by suppliers or host nations, may expose them to risk of liability under domestic legal regimes. ${ }^{127}$ Steve Kobrin has gone further, arguing that multinational corporations "should be held responsible directly for complicity in violations of human rights." 128

Still, litigation risk is only part of the story. In many cases, a promisee (e.g., GM) will have little real exposure for misconduct through the supply chain because there is no contractual privity or other legally-recognized connection between the defendant and the victims. In other cases, the breach of a KSR term may create no legal exposure for the promisee at all. The Beatles would not have been sued for performing segregated venues. They apparently believed, as do many KSR promisees, that a norm of segregation was intolerable and contract was one way to change it.

structure quite different from the facially bilateral contracts studied here because, among other things, the parties to it include both the buyers (brands) as well as trade unions and the International Labor Organization. Id. For a discussion of the Bangladesh Accord, see Jaakko Salminen, The Accord on Fire and Building Safety in Bangladesh: A New Paradigm for Limiting Buyers' Liability in Global Supply Chains?, 66 AM. J. COMP. L. 411, 412 (2018).

126. Although best developed in the U.S., other nations now permit class action lawsuits. See Debra Lyn Bassett, The Future of International Class Actions, 18 Sw. J. INT'L L. 21, 21-22, 27 (2011) (citing nations with class-action provisions and observing that "[f]or many years, class action litigation was virtually unknown outside of the United States").

127. Ruggie, supra note 12, at 831-32; see also John Ruggie (U.N. SecretaryGeneral's Special Representative for Business and Human Rights), Report of the Special Representative of the Secretary-General on the Issue of Human Rights and Transnational Corporations and Other Business Enterprises: Business and Human Rights: Mapping International Standards of Responsibility and Accountability for Corporate Acts, If 22-25, 30, U.N. Doc. A/HRC/4/35 (Feb. 19, 2007) ("Few companies may ever directly commit acts that amount to international crimes. But there is greater risk of their facing allegations of 'complicity' in such crimes.").

128. Stephen J. Kobrin, The Changing Role of Business in Global Society: New Challenges and Responsibilities, 19 Bus. ETHICs. Q. 349, 355 (2009). However, he considers civil litigation to be "unsystematic and unsatisfactory" in cases involving allegations of human rights abuses by multinational corporations. Id. at 350 . 


\section{REPUTATIONAL SANCTIONS AND REWARDS}

Financial exposure is not the only consequence of litigation: suing companies for failing to live up to social responsibility standards may also (or instead) have reputational effects. ${ }^{129}$ As a general proposition, companies care about their reputations; this concern can be harnessed to channel more socially responsible behavior by companies, and those with whom they contract. ${ }^{130} \mathrm{KSR}$ may be a reaction to bad publicity from normatively offensive conduct in a supply chain that cannot be cured by statements of corporate social responsibility.

Nike, for example, became the subject of damning attention in the early 1990s for the labor conditions in its suppliers' factories. ${ }^{131}$ Reports indicated that Nike suppliers forced female employees to run in extreme heat after not wearing regulation footwear to work $^{132}$ as well as the "denial of sick leave" and "forced overtime." ${ }^{133}$ Nike's response was largely organized around salvaging its reputation, and not necessarily addressing the underlying problems. It hired former U.N. Ambassador Andrew Young to conduct an internal assessment and report on changes at Nike. ${ }^{134}$ Critics accused Young's report of being "shallow." ${ }^{35}$ Nike continued to struggle with questions about the conduct of its suppliers. ${ }^{136}$ While it now purports to require those suppliers to abide by its "Code of Conduct," ${ }^{137}$ it is not clear whether it

129. Parella, supra note 64, at 910 ("[T]he informational effects of litigation . . . [have] reputational consequences for the affected organizations. Organizational change is a response to that reputational shaming.").

130. Claire A. Hill, Marshalling Reputation to Minimize Problematic Business Conduct, 99 B.U. L. REv. 1193, 1197 (2019) (developing an argument "that reputation can work better than it has to discourage problematic corporate conduct").

131. See generally Bob Herbert, Opinion, Brutality in Vietnam, N.Y. TIMES (Mar. 29, 1997), https://www.nytimes.com/1997/03/28/opinion/brutality-invietnam.huml [https://perma.cc/WSE8-BHMM]; WORKER RIGHTS CONSORTIUM

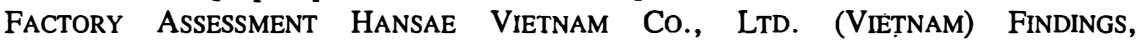
RECOMMENDATIONS, STATUS UPDATE 2-3 (Dec. 6, 2016), https://www.workersrights.org/wp-content/uploads/2019/10/WRC-Assessment-re-

Hansae-Vietnam-12.6.16.pdf [https://perma.cc/DTB8-NG2H] [hereinafter WORKER RIGHTS CONSORTIUM].

132. Herbert, supra note 131.

133. WORKER RIGHTS CONSORTIUM, supra note 131.

134. Dana Canedy, Nike's Asian Factories Pass Young's Muster, N.Y. TIMES (June 25, 1997), https://www.nytimes.com/1997/06/25/business/nike-s-asian-factoriespass-young-s-muster.html [https://perma.cc/9Z3Q-G9YD].

135. Id.

136. Nike InC., MAXimum Performance Minimum Impact: FY 16/17 SUSTAINABLE BUSINESS REPORT, 41-42 (2017), https://s1.q4cdn.com/806093406/files/doc_downloads/2018/SBR-Final-FY16-17.pdf [https://perma.cc/8RJ7-PDEH].

137. Id. at 41 . 
does so via contract or other pressures-or, indeed, does so at all. As recently as 2016, NGOs were reporting that Nike supplier factories in Vietnam still had problematic labor practices. ${ }^{138}$

Still, many companies care about their reputations, and worry about association with normatively offensive activity. Indeed, market actors can benefit from acting in ways that appear to be socially responsible. ${ }^{139}$ In at least some cases, the ability to positively market social responsibility requires a contractual response. The certification regimes discussed above, for example, may require that the party seeking the certificate demonstrate not only that its policies are normatively compliant, but that it has taken steps through the use of contract to achieve similar results elsewhere in the supply chain. KSR terms are, in other words, a response to both fears of reputational harm from normative deviation and a mechanism for enhancing reputation in ways that companies presumably-find beneficial.

\section{B. Vertical Deconstruction v. Normative Integration}

These normative pressures are a partial response to larger structural changes in the economy and society. To the extent KSR terms seek to transplant social norms through contract, these structural changes then also explain why parties may use contracts to achieve social responsibility.

The flattened multinational supply chain is perhaps the most notable example of this change. But, the end of the studio system in entertainment, the rise of free agency in sports, and the "gig economy," generally, all bespeak greater reliance on contracts, and perhaps a reduced or relaxed emphasis on the "firm" as such, which I call "vertical deconstruction." As firms become flatter and leaner, a corporate manager's normative footprint shrinks. In such cases, contract may be the mechanism of choice or necessity to (re)impose norms.

Vertical deconstruction is the opposite of the better studied phenomenon of "vertical integration." Vertical integration reflects the so-called "Coase-Williamson" theory that firms will produce internally what they need so long as the costs (and benefits) of doing so are less

138. WORKER RIGHTS CONSORTIUM, supra note 131.

139. Forbes has taken to ranking companies by their reputations for social responsibility. Karsten Strauss, The Companies with the Best CSR Reputations in 2017, FORBES, (Feb. 8, 2018, 11:36 AM), https://www.forbes.com/sites/karstenstrauss/2018/02/08/the-companies-with-the-bestcsr-reputations-in-2017/\#70acfde43873. 
(more) than the costs (benefits) of contracting outside the firm. ${ }^{140}$ When deciding whether to grow, the theory predicts that firms will acquire other firms using roughly the same calculation. ${ }^{141}$ Production within the firm would often be preferred, on this view, both because the transaction costs of contracting out may be comparatively high and managers within the firm would have greater power to command and control production through the ordinary employment relationship. ${ }^{142}$ But, there would always be tradeoffs between "hierarchy" and "market" and no single choice would be appropriate to all firms in all situations. ${ }^{143}$

Vertical integration characterized big business in the United States for much of the twentieth century. Major producers of steel, automobiles, and machinery "used the technologies of the second industrial revolution to achieve dramatic economies of scale through the mass production of standard goods with single-purpose or dedicated machinery." 144 This resulted in "vertical integration: [t]he manufacturer of the final good was likely to own upstream producers of key inputs, or downstream distributors, or both."145

Vertical integration brought with it not only economies of scale, but also a kind of normative integration, whereby those who ran companies could use their bully pulpits to change social norms within the firm. The historic example was the "company town," where "the paternalism of the owner extended beyond the bare-bones architectural requirements of factories or mines." 146 "Company towns, like Pullman, Illinois, and Coulee Dam, Washington, were communities in which a single business built, owned, and operated the entire town." ${ }^{147}$ The company would not only provide all of the material needs of the workforce, but also monitor and "improve" employees because doing

140. See R. H. Coase, The Nature of the Firm, 4 Economica 386, 394 (1937); Oliver E. Williamson, The Economics of Organization: The Transaction Cost Approach, 87 AM. J. Soc. 548, 558-59 (1981).

141. Oliver E. Williamson, The Vertical Integration of Production: Market Failure Considerations, 61 AM. ECON. REV. 112, 112-13 (1971).

142. Oliver E. Williamson, MarKeTS AND HierarchiEs: ANALYSIS AND ANTITRUST IMPLICATIONS: A STUDY IN THE ECONOMICS OF INTERNAL ORGANIZATION $117,127-29$ (1975).

143. Id. at $125-26$.

144. Gilson et al., supra note 11, at 437-38.

145. Id. See generally Alfred D. Chandler, JR., The Visible Hand: The MANAGERIAl ReVolution IN AMERICAN Business 1, 6-7 (1977).

146. John S. Garner, Introduction, in THE COMPANY TOwN: ARCHITECTURE AND SOCIETY IN THE EARLY INDUSTRIAL AGE 3-4 (John S. Garner ed., Oxford 1992) (labeling such places as "model company town[s]," in which there were numerous public amenities and programs to aid the residents).

147. M. Todd Henderson, The Nanny Corporation, 76 U. CHI. L. Rev. 1517, 1535 (2009). 
so was both economically and normatively beneficial to owners. ${ }^{148}$ In this environment-

Control was pervasive. Companies regulated drinking, smoking, gambling, cleanliness, speech, association rights, and also, more generally, morals. Companies would monitor employees in public and private settings, and would fire those who, in the view of the firm's bosses, were "straying from the path of virtue." 149

Perhaps the most notorious multinational example was "Fordlandia," Henry Ford's experiment in seeking to control foreign rubber costs while also controlling the lives and welfare of employees. ${ }^{150}$ In 1927, facing European control of the rubber market, Ford purchased about 2.5 million acres on the banks of the Tapajós River, a tributary of the Amazon about 600 miles from the Atlantic. ${ }^{151}$ He sought to replicate an idealized Midwestern town, with modern plumbing, hospitals, schools, sidewalks, tennis courts, and even a golf course. ${ }^{152}$ Fordlandia would be "an example of [Ford's] particular American dream, of how Ford-style capitalism-high wages, humane benefits and moral improvement-could bring prosperity to a benighted land." 153

While it is difficult today to know the impetus for these forms of "corporate nannyism," 154 it is not hard to see that the social norms in question were in certain respects simpler to transmit in a vertically integrated firm. The dominant normative vision of the founder could, if he wished, be imposed on workers out of paternalism, as a rade for

148. Todd Henderson characterizes this as "corporate nannyism," and reports that "Owners often couched their nannyism in benevolent and moral terms-'We keenly and genuinely feel our responsibility toward that which has been entrusted to us. We believe in the dignity of man and the worth of the individual." Id. at $1536 \mathrm{n} .45$ (quoting JAMEs B. Allen, THE COMPANY TOWN IN THE AMERICAN West 123 (1966)).

149. Id. at 1536-37 (quoting LINDA CARLSON, COMPANY TOWNS OF THE PACIFIC NORTHWEST 189 (2003)).

150. See Greg Grandin, Fordlandia: The Rise and Fall of Henry Ford's FORGOTTEN JUNGLE CITY 8 (2009).

151. See id. at $10,22,106$.

152. See id. at 8-9.

153. Id. This was despite Ford's having previously created and then closed a "sociological department" to ensure that workers "not debauch the additional money [they] receive [" from working at Ford. STEPHEN MEYER III, The Five Dollar DaY: Labor MaNagement and SOCIAL CONTROL IN THE Ford MOTOR COMPANY, 19081921, 124-25 (1981). This was likely due to Ford's desire that a worker "must show himself sober, saving, steady, industrious and must satisfy the superintendent and staff that his money will not be wasted in riotous living." FORD R. BRYAN, HENRY'S LIEUTENANTS 207 (1993).

154. Henderson, supra note 147 , at 1536 n. 45. 
improved performance, or some combination. Doing so required little more than the will and resources of the firm which, in many cases, simply meant the will of a visionary or controlling manager.

Today, however, it is highly unlikely that the modern equivalent of Henry Ford would venture anything like Fordlandia. Apple did not need to create "Jobsville" in Asia-it hired Foxconn, instead. ${ }^{155}$ Doing so meant that Apple would, in the words of Gilson, Sabel, and Scott (GSS), "vertically disintegrate" its production regime. ${ }^{156}$ According to GSS, "vertical disintegration" occurs when firms "cannot themselves maintain cutting-edge technology in every field required for the success of their products." ${ }^{157}$ Vertical disintegration means that companies buy rather than make; they use contract rather than command to obtain the goods and services they need.

When it comes to social and environmental norms, the changes we see may be better described as vertical deconstruction, because they are not merely organizational, and the social structures that matter are not disintegrating; they are changing. Consider, by analogy, some effects of social media. The "unique character of online interactionconstraints on information, a linear sequentiality, the hyper-connectivity and speed of online communication, and, to the degree that it is present, anonymity between users-render . . . explosions of expression more likely to occur online than in the offline world." ${ }^{158}$ That

155. Patrick Moorhead, Who are Apple's iPhone Contract Manufacturers?, FORBES (Apr. 13, 2019, 6:54 https://www.forbes.com/sites/patrickmoorhead/2019/04/13/who-are-apples-iphonecontract-manufacturers/.

156. See Gilson et al., supra note 11, at 434. Although they were not the first to observe this phenomenon, theirs has been the leading contribution to the legal literature on it. Compare Richard N. Langlois, Chandler in a Larger Frame: Markets, Transaction Costs, and Organizational Form in History, 5 ENTERPRISE \& SOC'Y 355, 355 (2004) ("In 1977, . . .the large, vertically integrated 'Chandlerian' corporation had dominated the organizational landscape for nearly a century. . . . A quarter century later, however, the Chandlerian firm no longer dominates the landscape."), with Naomi R. Lamoreaux et al., Against Whig History, 5 ENTERPRISE \& Soc'Y 376, 376-77 (2004) ("By the end of the twentieth century, it had become clear that . . . the acme of capitalist economic organization-the large, vertically integrated, horizontally diversified, managerially directed corporation-was clearly in retreat."). As Langlois has elsewhere observed:

Rather than seeing the continued dominance of multi-unit firms in which managerial control spans a large number of vertical stages, we are seeing a dramatic increase in vertical specialization-a thoroughgoing 'deverticalization' that is affecting the traditional Chandlerian industries as much as the high-tech firms of the late twentieth century.

Richard Langlois, The Vanishing Hand: The Changing Dynamics of Industrial Capitalism, 12 J. IND. \& CORP. CHANGE 351, 352 (2003).

157. Gilson et al., supra note 11 , at 434 .

158. Bryan Druzin \& Gregory S. Gordon, Authoritarianism and the Internet, 43 LAW \& SOC. INQUIRY 1427, 1428 (2018). 
expression may generate and transmit social norms in ways that earlier social mechanisms could not. ${ }^{159}$

Although social media did not cause vertical deconstruction, both bespeak a state of the world in which norms about social, economic, and environmental responsibility are at once increasingly contested and yet salient to economic actors. As social and economic structures shed their hierarchical character, other mechanisms, including contract, appear to pick up the slack.

\section{PROMISING JUSTICE: HOW MIGHT KSR ACTUALLY WORK?}

The foregoing suggests a puzzle: there may be good normative and structural reasons for companies to want to use contract to achieve social responsibility, but if doctrine is ill-equipped to make it happen, or parties such as HP deliberately render these terms un(der)enforceable, how will it work? More concretely, if parties understand that KSR terms are unlikely to be enforceable in any ordinary sense, why not simply rely on corporate social responsibility and voluntary codes of conduct? What does KSR add?

This becomes all the more puzzling when one considers that actual KSR terms themselves are unlikely to be publicly available, and so they will not even have the marketing effect that we may cynically attribute to .CSR. We do not, for example, generally get to see the terms between General Motors and its actual suppliers, for legitimate competitive reasons; we only see the form language that they say they use. So, these otherwise private instruments may have limited reputational or similar benefits. ${ }^{160}$

The problem of uncertain enforceability is not new to contract theory. The large literature on relational conracting seeks, in essence, to answer the question: Why use formal contract if it does little legal work ${ }^{161}$ I situate KSR terms in that tradition because relationalism has

159. See, e.g., Nancy K. Baym \& Danah Boyd, Socially Mediated Publicness: An Introduction, 56 J. BROADCASTING \& ElEC. MEDIA 320, 320 (2012) ("[S]ocial media complicate[s] what it means to be public, to address audiences, and to build publics and counterpublics."); see also Eric Arias, How Does Media Influence Social Norms? Experimental Evidence on the Role of Common Knowledge, 7 POL. SCI. R. \& METHODS 561, 564-65 (2019) (reporting on study of social effects of media broadcasts). Social Media Reshapes Journalism, Austin AMERICAN-STATEMAN (Sept. 1, 2012, 12:01 AM), https://www.statesman.com/article/20120901/NEWS/309013975 [https://perma.cc/GHZ5-WQHT] (explaining how social media has changed news consumption and production).

160. I reserve for future work more systematic empirical studies of KSR.

161. See, e.g., Baker \& Choi, supra note 10, at 561 ("If the parties perform obligations, or fulfill their promises, out of the fear of reputational or relational sanctions, why do they bother to write enforceable formal contracts in the first place?"). 
strong explanatory power when traditional doctrine does not. While not all contracts that contain KSR terms are (or need be) "relational" in a conventional sense, ${ }^{162}$ relationalist insights seem especially apt at explaining the promise of KSR, as well its limits.

\section{A. Form v. Norm: Relational Contracting Theory}

For relationalists, un(der)-enforceability is not necessarily a bug but a feature of contract. In 1963, University of Wisconsin Law Professor Stewart Macaulay published a path-breaking study which found that formal law, such as the written contract or black letter doctrine, often matters little in business decision-making. ${ }^{163}$ Ever since, the task for most relationalists has been to understand the role that formal contract plays in the design, implementation, and enforcement of business transactions-the interplay of the "real deal" and the "paper deal." 164

Lisa Bernstein was among the first to recognize that formal and informal are not all-or-nothing choices but instead are a blend reflecting the parties' negotiated preferences for those things. Often, she found that informal community norms proxy for formal conract rules. ${ }^{165}$ In many cases, these social norms will be embedded in community structures that generate standards of conduct that will supplement or supplant formal legal mechanisms. ${ }^{166}$ Bernstein's study of trading

162. Goetz and Scott famously opined:

A contract is relational to the extent that the parties are incapable of reducing important terms of the arrangement to well-defined obligations. Such definitive obligations may be impractical because of inability to identify uncertain future conditions or because of inability to characterize complex adaptations adequately even when the contingencies themselves can be identified in advance.

Charles J. Goetz \& Robert E. Scott, Principles of Relational Contracts, 67 VA. L. REv. 1089, 1091 (1981).

163. Macaulay, supra note 14, at 61-63.

164. Stewart Macaulay, The Real Deal and the Paper Deal: Empirical Pictures of Relationships, Complexity and the Urge for Transparent Simple Rules, 66 MOD. L. REV. 44, 44 (2003).

165. See Lisa Bernstein, Merchant Law in a Merchant Court: Rethinking the Code's Search for Imminent Business Norms, 144 U. PA. L. REv. 1765 (1996); Lisa Bernstein, Opting Out of the Legal System: Extralegal Contractual Relations in the Diamond Industry, 21 J. Legal STUD. 115 (1992) [hereinafter Diamond Industry]; Lisa Bernstein, Private Commercial Law in the Cotton Industry: Creating Cooperation Through Rules, Norms, and Institutions, 99 MrCH. L. REv. 1724 (2001).

166. Thus, a quarter-century ago, she argued:

[T]he effects of social norms and other relational factors on parties' contracting behavior must be taken into account in any theory of default rules that seeks to influence, interpret, or reconstruct the contracting process. . . . . [U]nderstanding a contracts' relational context may help an 
behavior among Jewish diamond dealers in New York, for example, revealed sophisticated decision-making within the community about the uses (or not) of formal contract mechanisms, such as consignment agreements. ${ }^{167}$ Her key finding was that one set of privately proscribed rules and norms governed transactions within the community, ${ }^{168}$ and another, more formal system would mediate between that community and the outside world. ${ }^{169}$

Formality was, in Bernstein's observation, determined by the boundaries of community. ${ }^{170}$ Within a tightly knit community, informality prevailed as a less costly way to promote productive cooperation in private ordering than formal contract. ${ }^{171}$ However, as interactions with outsiders grew in number and significance (e.g., because merchants borrowed from banks outside the community), the community's social norms had diminishing force. ${ }^{172}$ Those norms were neither intelligible to, nor enforceable against, outsiders. ${ }^{173}$ Instead, the formal mechanisms of law in its conventional sense were recruited to manage exchange relations at that boundary. ${ }^{174}$ Without formal mechanisms to buttress informal arrangements, Bernstein noted, "courts tend to interpret the meaning of an intraindustry consignment

adjudicator more accurately determine the parties' subjective intent, and may help courts and legislatures more accurately assess the social desirability of different types of legal default rules.

Lisa Bernstein, Social Norms and Default Rules Analysis, 3 S. CAL. INTERDISC. L.J. 59, 90 (1993).

167. See Bernstein, Diamond Industry, supra note 165, at 155-56.

168. Id. at 116 (" $[\mathrm{T}]$ he diamond industry is unique in its ability to create and, more important, to enforce its own system of private law.").

169. See id. at 154.

170. See id. at 140.

171. See id.

172. See id. at 154 .

173. Thus, legal counsel to the diamond merchants advised dealers that they had to use the formal notice-filing system created by the Uniform Commercial Code to protect their interest in consigned diamonds in the event a consignee went into bankruptcy. Id. at $155 \mathrm{n} .69$ ("[T] he UCC will give you protection if you adequately describe your diamonds and file a UCC-1 Financing Statement . . . . This will give you a legal leg to stand on if you unfortunately have to seek the return of your merchandise from a bank or a trustee in bankruptcy."). Under the Uniform Commercial Code, a consignor of diamonds would risk losing those diamonds to a creditor of the consignee who had a security interest in the consignee's inventory. See UCC §§ 9-317 to 9-319 (AM. LAW INST. \& UNIF. LAW COMM'N 2000 Supp. 2019). The only way a consignor (conditional seller) of the diamonds could protect itself would be by filing a "financing statement" in the office of the secretary of state where the consignee was located. See id. § 3-317. This is, for all practical purposes, a highly formalistic act having no meaning within a closed religious community. It would, however, matter both legally (and probably culturally) to sophisticated lenders not from that community.

174. See Bernstein, Diamond Industry, supra note 165, at 154. 
agreement in ways that are strongly at odds with industry custom and the intent of the original contracting parties." 175

This has important implications for understanding the operation of KSR terms. These terms often seek to use formal contract mechanisms to traverse community norms, to inject into one community the social values of another. Thus, the supplier that promises GM that it will not use prison labor may have to renounce a local social norm that permits it. ${ }^{176}$ If Frances McDormand obtains a movie production company's agreement to hire a more diverse cast and crew, she may be asking them to agree to alter their social norms about gender, race, and ethnicity to take a social posture aligned with hers. KSR would use contract to alter social norms of the promisor that might otherwise permit, promote, or insulate conduct that offends the (claimed or actual) social norms of the promisee.

Unlike the typical relational contract, therefore, KSR promisees may demand elaborately formal contract terms as seen in, for example, the Model Terms discussed above. ${ }^{177}$ We use formal mechanisms to the extent that we cannot trust informal ones. ${ }^{178}$ As to the commercial core of the contract, it is likely that the parties will share norms around, for example, trust and reciprocity. ${ }^{179} \mathrm{KSR}$ terms, especially as they would be implemented by the ABA Model terms, reflect the fact that, even if the parties share norms around the commercial core, they may not do so with respect to social matters tangential to it, such as the treatment of low-wage workers, ethnic minorities, or the environment. We will achieve "social justice" through KSR not by leaving parties to trust, reciprocity, or local norms, but instead through elaborate contractual specification to displace or alter those norms, even though those terms may be unenforceable by courts.

175. Id. at 156 .

176. Of course, the U.S. does not have a stellar record on the use of convict labor. See David M. Oshinsky, Worse Than Slavery: Parchman Farm AND THE ORDEAL OF JIM CROW JUSTICE 46 (1996) (explaining that the annual mortality rate for Mississippi's virtually all-black convict population in the 1880 s was nine to sixteen percent); Alex Lichtenstein, Twice the Work of Free Labor: The Political ECONOMY OF CONVICT LABOR IN THE NEW SOUTH 36 (1996) (observing that convict leasing was never declared unconstitutional).

177. See supra pp. 113-14.

178. Cf. Ricard Gil \& Giorgio Zanarone, Formal and Informal Contracting: Theory and Evidence, 13 ANN. REv. L. \& Soc. SCI. 141, 143 (2017) ("Most economists define relational contracts as a synonym for our informal contracts-that is, agreements that cannot be verified by third parties and hence must be self-enforcing . . . .").

179. See Macaulay, supra note 14 , at 63 ("[T]ypically in manufacturing industry we are not dealing with questions of taste or judgment ...."). 


\section{B. Contingency and Contracting for Normative Innovation}

Relationalists often focus on the role that contract plays in technological innovation, such as the development of a new pharmaceutical or software program. ${ }^{180}$ These contracts present a challenge for conventional microeconomic theories of contract and firms because they require levels of informal trust and reciprocity thought to be incompatible with arms-length bargaining and yet lack some of the conventional command-and-control mechanisms one would expect to find within a vertically-integrated firm to manage those problems. ${ }^{181}$ Contracts for innovation are open-ended and uncertain as to outcome, which can make their terms difficult to plan and specify ex ante. ${ }^{182}$ They can require the parties to reveal sensitive information to one another, which can leave them exposed to opportunistic behavior, whether by seeking to capture a disproportionate share of the gain or to litigate excessively to shift losses. ${ }^{183}$ Gilson, Sabel and Scott (GSS) have argued that contracts for innovation reflect
a rich braiding of explicit (i.e., legally enforceable) obligations and implicit (i.e., legally unenforceable) obligations. The explicit and implicit obligations interact within a formal governance structure that regulates the exchange of highly revealing information but does not necessarily impose legally enforceable obligations to buy or sell anything. ${ }^{184}$

Contract social responsibility can be seen as seeking analogous innovation, and functioning like the braided contracts that GSS observe. The "formal" will be the substantive terms that firms like GM, HP and Starbucks may ask their suppliers to agree to, as well as procedural mechanisms such as the ABA Model Terms, to implement them. Some of these terms, in particular indemnification, are likely to be enforceable, creating economic recourse with potential bite in the event

180. See Gilson et al., supra note 11 , at $458-59$.

181. See id. at 433-34.

182. See id. at 435.

183. Gilson, Sabel, and Scott have argued that contracts for innovation have three characteristics: (i) the goal of producing an "innovative" product "whose characteristics, costs, and manufacture, because of uncertainty, cannot be specified ex ante"; (ii) the parties must collaborate to develop the product because "neither party alone has the capacity to specify and develop the product's characteristics, costs, and methods of manufacture"; and (iii) "the process of specification and development will be iterative." Id. at 451 .

184. Id. at 435. See also Gilson, Sabel \& Scott, Braiding, supra note 16, at 1415-16; Gilson, Sabel \& Scott, Contract and Innovation, supra note 16, at 172-74. See generally Gilson, Sabel, \& Scott, Text and Context, supra note 16. 
of breach. Others create options to direct the counterparty's governance in ways that may be unenforceable, but whose threat may induce compliance. If, for example, GM has the articulated rights suggested by the Model Terms to cause the termination of problematic employees or subcontracts at a supplier, the supplier may think more carefully ex ante about who it does business with.

The braiding of these terms may not require the promisor to perform the substantive KSR terms perfectly. But, as with HP's program, it may plausibly require the promisor to reveal sensitive information about its compliance with the promisee's normative requirements. ${ }^{185}$ That sensitive information may, among other things, create incentives for the parties to align their goals and resolve their differences. KSR terms would be components of what Bernstein calls "network governance," which occurs when firms "operate in a market of highly interconnected firms-a network that itself functions as a contract governance mechanism." 186

In many settings, the uncertainty of contract terms may be viewed as either a flaw in their drafting, or in the background law, or both. When uncertainty is low, parties are thought to resort to more specific and formal contract terms. ${ }^{187}$ If, however, we view substantive KSR terms as contracts for normative innovation, it becomes easier to explain their contingency. They create not a fully enforceable obligation, but one whose contingency both encourages iterative improvement by the promisor and creates the possibility of some kind of enforcement by the promisee. In many cases, for example, immediate and full compliance with HP's substantive Code of Conduct may well be unrealistic, as and to the extent the terms are normatively alien to the promisor (or, as in the example above, its promisor). Thus, progress may be the best that HP, or any of us, can hope for. This places a fair amount of trust and discretion in HP's hands which, for the reasons discussed below, may be a problem. ${ }^{188}$ But at minimum, promises of the sort that HP appears to extract from its suppliers would seem to supplement and implement existing norm regimes in ways that may plausibly deliver on their promise of justice.

185. See supra note 183 and accompanying text.

186. Bernstein, supra note 15 , at 563.

187. Gilson, Sabel, \& Scott, Text and Context, supra note 16, at 44 ("When uncertainty is low, legally sophisticated parties in bilateral relationships can turn to bespoke contracting . . . . [A]s uncertainty increases, legally sophisticated parties will resort to an interpretive regime that braids state-contingent rules with general standards that require a context for interpretation, while at the same time guiding the court in what context matters.").

188. See discussion infra Section III.B. 


\section{Granularity, Specificity and the Expressive and Educative Functions of Contract}

Even if we assume for the moment that KSR terms are legally unenforceable, they may play an important role in achieving their social responsibility goals by expressing in detailed legal language the normative regime to which the parties agree. The expressive effects of these terms may not only affect the norms of personnel associated with the parties, but also create mechanisms for educating the parties in order to induce the agreed normative change.

The expressive theory of law starts from the assumption that law may be un- or under-enforceable in a legal sense, but that it can nevertheless affect social norms. ${ }^{189}$ Expressive theories of law would say that those who make law do so not merely because of the instrumental "results they expect from those who fear its sanctions, but also because they wish to make more and perhaps richer statements about themselves, their institutions and the larger social setting in which law and legal messages are generated and transmitted." ${ }^{190}$ Law may be especially effective in this regard when it "announces or signals a change in social norms unaccompanied by much in the way of enforcement activity." 191

The literature on expressivism is largely foreign to the world of contract, which is surprising. ${ }^{192}$ If we think that expressivism requires some legal statement to communicate the norms in question, it is not

189. See, e.g., Robert Cooter, Expressive Law and Economics, 27 J. LEGAL STUD. 585, 586 (1998) ("According to the expressive theory of law, the expression of social values is an important function of the courts or, possibly, the most important function of courts.") (footnotes omitted); see also Cass R. Sunstein, On the Expressive Function of Law, 144 U. PA. L. REv. 2021, 2022 (1996) ("Many people support law because of the statements made by law, and disagreements about law are frequently debates over the expressive content of law."). The idea that law may have an expressive function is not especially new. As Matthew Adler has observed, it dates back at least to the 1960s, when philosophers considered the expressive functions of criminal punishment. See Matthew D. Adler, Expressive Theories of Law: A Skeptical Overview, 148 U. PA. L. ReV. 1363, 1369 (2000) (citing Joel Feinberg, The Expressive Function of Punishment, 49 MoNIST 397 (1965)); see also H.L.A. HART, PUNISHMENT AND RESPONSIBILITY (1968) (discussing the ways in which criminal law expresses social judgment).

190. Jonathan C. Lipson, The Expressive Function of Directors' Duties to Creditors, 2 STAN. J.L. Bus. \& Fin. 224, 262-63 (2007).

191. Sunstein, supra note 189, at 2032 (emphasis omitted).

192. Cf. Gillian K. Hadfield, An Expressive Theory of Contract: From Feminist Dilemmas to a Reconceptualization of Rational Choice in Contract Law, 146 U. PA. L. Rev. 1235, 1267 (1998) ("By seeing choice as routinely expressive, we are not at the end of contract reasoning-we are at the beginning. What reasons could there be for enforcing a promise when it is expressive and not instrumental?"). 
hard to imagine that in terms of sheer volume, contract creates more absolute expression than any other type of legal instrument. ${ }^{193}$

It is not, on this view, difficult to see the expressive effect that substantive KSR terms might have between the parties. Even if the terms are unenforceable, they will involve levels of specificity and granularity that may enhance the transmission of the norms in question. Specificity means that, unlike CSR or public law, the KSR terms are articulated by one party to the other and the plausible subject of negotiation and ultimately agreement thereafter. ${ }^{194}$ While they may be born as insourced norms or transactional boilerplate, they live as the embodiment of some kind of agreement between the parties. Granularity reflects the detail of those terms. Again, unlike CSR or public law, KSR terms will describe in.sometimes painstaking, lawyerly detail the conduct that the underlying norms permit, require, and forbid.

Thus, the mere act of incorporating human rights or other "soft" norms into contracts as certification standards increases the likelihood that individuals within the firms in a position to affect (and be affected by) those norms will read them. Indeed, on this view, HP's requirement that its suppliers promise to read its code of conduct may be all and only what expressive theories of law would predict. The process of articulating un(der)-enforceable terms influences the norms of both parties as they negotiate, internalize and operate under the meaning and implications of the terms. KSR terms may be uncertain as to enforceability, but they will probably be negotiated and assessed by the parties and their counsel, and that fact alone may make some difference-possibly a big difference-in transmitting norms. ${ }^{195}$

193. For the most part, expressivism has focused on public law, such as Supreme Court opinions, not the expressive functions of the words that market actors choose to use to articulate their private ordering. See Sunstein, supra note 189, at 2028 ("[T]hre close attention American society pays to the Court's pronouncements is connected with the expressive or symbolic character of those pronouncements."). Even sophisticated contract analysts sometimes assume that the audience for contract language is courts, that is to say public actors, without considering the effect that the language may have on the parties themselves, whether or not enforceable. See Gilson, Sabel, \& Scott, Text and Context, supra note 16, at 55. As GSS note:

[L]egally sophisticated commercial parties turn to creative contract design to accomplish two objectives: first to provide clear instructions to courts as to the appropriate mix of text and context; and, second, in light of those instructions, to invite courts to retain their historic superintending role to guard against opportunistic behavior.

Id.

194. Alan Schwartz \& Robert E. Scott, Contract Theory and the Limits of Contract Law, 113 YALE L.J. 541, 573 (2003) (“[T]he writing expresses the parties' solution to the contracting problem at issue.").

195. To be sure, important empirical questions here will involve whether various parties in the supply chain have counsel and, if so, how they function with 
Lawyers may have a special role here. Chris Johnson, formerly general counsel of GM North America and the motive force behind the GM terms noted above, has observed that lawyers play "a critical role for business clients" in transmitting norms involving human rights through supply chain and similar agreements. ${ }^{196}$

Lawyers discern the legal, financial, ethical, and moral risks of noncompliance with the rule of law including local, state, and federal laws and international norms and rules. Lawyers help corporate boards and CEOs recognize both the risks of potentially violating laws and the long-term rewards of acting within those laws, even when others might pursue short-term rewards while tolerating unacceptable risks. ${ }^{197}$

The Model Terms discussed above are a product of the American Bar Association, and likely reflect an effort to recruit business lawyers to the cause of advancing human rights by making such terms seem standard and perhaps authoritative. They also empower lawyers to act on normative aspirations that may be important to them, but which life as a corporate lawyer may have suppressed or ignored. ${ }^{198}$

To work, expressivism relies on "norm entrepreneurs," individuals who "in the private sphere attempt to change norms by identifying their bad consequences and trying to shift the bases of shame and pride." ${ }^{199}$ Although we do not typically think of lawyersespecially business lawyers-as "norm entrepreneurs," projects like the ABA Model Terms, in general, and the specification of social

respect to these transactions. There is no reason to think that they necessarily act like U.S. lawyers.

196. See Johnson Jr., supra note 44, at 1121-22.

197. Id. at 1122 .

198. The introduction to the ABA Model Contract Clauses to Draft Human Rights Protections in International Supply Contracts implores:

We cannot stand by when children are trafficked and traded or when workers die in factory collapses and fires. The hope is that following the steps outlined in the ABA Model Principles will help eradicate labor trafficking and child labor from supply chains, making a difference to real people-their health, safety, and freedom-and, in some cases, saving lives.

Snyder \& Maslow, supra note 42, at 1094. Perhaps this is the start of a response to Robert Gordon's observation that "[t]here is certainly almost nothing written on a subject about which the organized bar, indeed any reflective practitioner, ought to know a lot - the likely social effects of different kinds of law practice." Robert W. Gordon, Lawyers, Scholars, and the "Middle Ground", 91 MrCH. L. REv. 2075, 2088 (1993).

199. Sunstein, supra note 189, at 2030-31. For a discussion of the idea of the "norm entrepreneur," see Eric A. Posner, Symbols, Signals, and Social Norms in Politics and the Law, 27 J. LEGAL STUD. 765, 773-76 (1998). 
responsibility terms in contracts may require us to rethink that position. ${ }^{200}$

Similarly, KSR terms may perform an educative function. Like expressivism, educative theories assume that law is important for what it teaches, and not merely how it affects behavior. Scholars have, for example, long understood the Supreme Court and the opinions its Justices write as educative in the sense that they teach readers something about the Court's values and values of significance in our government. ${ }^{201}$ Thus, Christopher Eisgruber has argued that the Supreme Court offers "inspirational" education because it has "both the incentive and the ability to craft uniquely powerful exhortations to the American people." 202

In the case of KSR, the interior remedies to which the parties agree may involve an educative process. ${ }^{203}$ Starbucks, for example, uses a third-party auditor to produce "scorecards" of suppliers' compliance with its ethical sourcing standards. ${ }^{204}$ Following discovery of a violation, Starbucks says it will first work with the supplier to "develop and implement a corrective action plan." ${ }^{205}$ If that doesn't work, the supplier is considered in material breach, which "may result in cancellation of any current orders and/or termination of Starbucks contractual relationship with the supplier." ${ }^{206}$

In other words, even if KSR terms fail in a conventional legal sense, they are likely to express norms in a way that is tailored to the interests and needs of the parties and, in that tailoring process, to internalize those norms in ways that would not be possible through

200. There has been a recognition that lawyers are "norm entrepreneurs" in the development of professional and ethical 'standards. Liwen Mah, The Legal Profession Faces New Faces: How Lawyers' Professional Norms Should Change to Serve a Changing American Population, 93 CAL. L. REv. 1721, 1747 (2005) ("Through modifications to the Model Rules of Professional Conduct, the bar can be Posner's norm entrepreneur, encouraging lawyers to adjust their norms regarding neutrality, client autonomy, and confidentiality.").

201. The idea that the Court is an educative institution is often sourced to Eugene V. Rostow, The Democratic Character of Judicial Review, 66 HARV. L. REV. 193, 208 (1952).

202. Christopher L. Eisgruber, Is the Supreme Court an Educative Institution?, 67 N.Y.U. L. REV. 961,964 (1992).

203. See supra Section I.B.2.

204. Starbucks Coffee Company, C.A.F.E Practices Generic SCORECARD (Dec.

https://globalassets.starbucks.com/assets/4a67ce15e63b4ea18461ff65a540feb3.pdf [https://perma.cc/JLQ9-TCL6].

205. Starbucks Coffee Company, Starbucks Disclosure in COMPLiance with California TRansparency IN SUPPly Chains ACT OF 2010 (SB 657) https://globalassets.starbucks.com/assets/2994ceff517a44aca17df6f1237c4c13.pdf [https://perma.cc/A4H8-66EQ].

206. Id. 
other legal mechanisms. Moreover, the educative mechanisms parties build into these contracts evidence some commitment to collaborative improvement where compliance has fallen short.

In these ways, KSR can be seen as steering a path between soft and hard law. Soft law by itself may produce cynical indifference; hard law by itself may produce resistance. KSR may be something different, a hybrid that recruits the look and feel of hard law even as it emanates from and seeks to implement the substance of soft law through indirect, sometimes non-instrumental techniques. KSR promises justice not because its terms will produce binding judgments in all cases, but because it is an incremental and plausible step in larger efforts to change norms reflecting a wide range of social, economic-and environmental concerns.

\section{The Problem of Opportunism}

Like all promises, the promise of justice through KSR can certainly be broken. For many contract analysts, the most corrosive form of breach is one that is opportunistic. "The crucial question" in contracting for technological innovation, Gilson, Sabel and Scott argue, is "whether one's counterparty acts opportunistically-that is, takes advantage of the collaborative process to capture a larger share of the jointly created surplus (say, by using jointly produced information for its private benefit)." ${ }^{207}$ Often, this is an unwelcome byproduct of reliance on norms at the expense of formal contract terms. Opportunism might, for example, reflect one party's making significant relationshipspecific invesments in research and development in reliance on the other party's unenforceable suggestions of future business, only to see the counterpart defect, perhaps taking some or all of the jointlyproduced gains with them. ${ }^{208}$ To Gilson, Sabel and Scott, and many other contract analysts, the principal work of formal terms is to deter and remedy opportunism. ${ }^{209}$

Opportunism in KSR could take at least two general forms. First, the KSR promisor (e.g., the seller under a multinational supply chain

207. See Gilson et al., supra note 11 , at 455 .

208. See generally Gilson, Sabel, \& Scott, Text and Context, supra note 16, at 60-61 (discussing opportunistic conduct in bio-tech/pharmaceutical contracts for drug development).

209. See id. at 56 ("Fidelity to the contractual text thus reduces the need for resort to context to address unanticipated events, as well as the opportunity for a losing party to exploit the court's discretion by seeking to persuade it to reallocate losses assigned to the losing party by the contract."). Cf. Jennejohn, supra note 17, at 292 (2016) (" $[R]$ ather than being single-minded tools for addressing only the opportunism threat that has preoccupied much scholarship in contract economics, contract provisions can be multivalent, responding to multiple hazards simultaneously."). 
agreement) may agree to terms that it knows it cannot perform in order to gain the buyer's business. Knowing how difficult it may be to monitor and verify KSR performance, however, the promisor may take the risk. If the breach is later discovered due to some foreseeable tragedy (e.g., the Rana Plaza disaster, discussed above), the promisee may suffer real reputational harm. If the promisor operated on thin margins or otherwise rendered itself judgment proof, the promisee will be stuck with the loss. The contingency of KSR terms, coupled with competitive pricing pressure in global trade, may make it easy for the promisor to say "yes," even if it knows that "no" is the more plausible answer.

Second, the KSR promisee (e.g., the buyer) may demand KSR terms that are costly for the promisor (seller) to honor, but for which the promisee may not wish to pay. A buyer's initial purchase price may amortize some of the KSR costs (e.g., better wages for the seller's workers), but if the buyer has no fixed obligation to buy from a seller at a stated price and quantity, the seller runs the risk that it will end up like Takata, forced by GM to reduce the price of airbags even as doing so eventually cut into their quality. ${ }^{210}$ If $\mathrm{GM}$ has the market power to compel its sellers to agree to its norms, it may also have the power to defect later, if or when it believes that it needs to.

There are many other ways that parties to KSR terms could behave opportunistically. But in most cases, the risk of opportunism will be a function of practical and doctrinal limits to legal enforceability, against a backdrop of differing social norms. KSR terms, like all contract terms, are imperfect mechanisms for reducing or limiting the incidence of opportunistic behavior.

\section{E. Problems of Cooptation and Fragmentation}

Just as contingency may enable one contract party to defect with impunity, so may it permit both parties to betray KSR's purportedly deeper promises of social justice. Contractual promises to achieve social responsibility may, for example, result in the "cooptation" that has allegedly beset the larger social movements that frame KSR. Its duality may also permit and promote social fragmentation.

"Progressive" legal scholars, including those concerned with the norms in play in KSR, have often worried about the problem of

210. There have been allegations that Takata's deadly airbags were the product of an effort by GM to cut costs on airbags, even though GM knew that they might be more dangerous than more expensive models. Hiroko Tabuchi, $A$ Cheaper Airbag, and Takata's Road to a Deadly Crisis, N.Y. TIMEs (Aug. 26, 2016), https://www.nytimes.com/2016/08/27/business/takata-airbag-recall-crisis.html [https://perma.cc/7WK6-PN8F]. GM's previous airbag supplier, Autoliv, apparently lost GM business to Takata over the price of the airbags. Id. 
cooptation. This is the idea, Orly Lobel argued in a provocative 2007 paper, that reliance on formal legal mechanisms "narrows the causes, deradicalizes the agenda, legitimizes ongoing injustices, and diverts energies away from more effective and transformative alternatives."211 Rather than advancing social justice, many progressive scholars worry that legal activism "actually reinforces existing institutions and ideologies." 12 For example, as Derrick Bell famously warned, civil rights litigation may be a "leaky boat"; 213 "real progress," he argued, "can come only through tactics other than litigation." 214

Lobel argued that extralegal mechanisms may be just as vulnerable to cooptation as those of the legal system, and that we must therefore "question whether the new extralegal politics that are proposed and celebrated are capable of producing a constructive theory and meaningful channels for reform, rather than passive status quo politics." 215 For example, civil'society reform may have begun as a politically progressive movement focused on decentralized and nonstate social change, but it was recruited by politically conservative groups to advance a deregulatory and social agenda contrary to the vision of the original movement.

Corporate social responsibility may be a good example of cooptation. Because it presumptively creates no legally enforceable obligations, CSR has gone from a project that aspired to promote progressive goals on the environment and labor protections to one criticized as little more than "marketing, recruitment, public relations, and 'greenwashing' strategies." 216 Whatever social responsibility CSR sought to achieve stopped at the "corporate" element: by giving corporate managers greater discretion to act, with reduced risk of legal exposure, CSR may produce half-measures. At worst, it would lull us into believing that corporations were producing real and positive change, when in fact managers were fleecing both shareholders and the supposed beneficiaries of CSR. As Payne and Periera observe, "[b]usinesses can cynically adopt or sign onto corporate social responsibility . . . initiatives without any intention of changing behavior." 217 "Indeed," they continue, "signing on to these global initiatives may provide the necessary cover for businesses to continue

211. Lobel, Paradox of Extralegal Activism, supra note 22, at 939 (emphasis omitted).

212. Id. at 939 .

213. Derrick Bell, And We ARe Not SAved: The Elusive Quest for RACIAL JUSTICE 70 (1987).

214. Derrick Bell, Foreword: The Civil Rights Chronicles, 99 HARv. L. REv. 4, 24 (1985).

215. Lobel, Paradox of Extralegal Activism, supra note 22, at 971.

216. Id. at 976 .

217. Payne \& Pereira, supra note 21, at 68. 
or increase human rights abuses." ${ }^{218}$ While recent pronouncements of support for CSR by the Business Roundtable have gained media attention, there is good reason for caution. ${ }^{219}$

KSR may be seen as a step in the right direction, because it would either complement or constrain CSR with terms that reduce discretion and appear to function like real law. However, it should be clear by now that KSR is, at best, only a step in that direction. It cannot endow reluctant or hostile parties with the will or ability to achieve social justice that a lack of resources or local normative pressure impede. Like CSR before it, the pliability of KSR presents risks of cooptation that defy easy solutions. Companies like GM and Starbucks may talk a good social-responsibility game, but nothing requires them to enforce the KSR terms for which they may have bargained. Frances McDormand may urge a large audience to negotiate for inclusion riders, but that does not mean that she or others in a position to do so actually will. ${ }^{220}$

And, because business lawyers are likely to play an outsized role here, they may bring with them the risk-aversion that characterizes their practice. To make social responsibility a problem that business lawyers solve may, to some, make the problem worse, not better. ${ }^{221}$ Lawyering KSR may be a Trojan Horse, a false flag of change that cannot come without much greater effort than contract terms.

At the same time, KSR may also exacerbate problems of fragmentation, in two related ways. First, "fragmentation" is often understood as the problem that arises in international law when a single state is subjected to multiple conflicting legal regimes. ${ }^{222}$ For example, the World Trade Organization (WTO) may proscribe a set of trade standards that conflict with regional trade standards, as happened with

218. Id.

219. See supra note 24 and accompanying text.

220. See Cara Buckly, Inclusion Rider? What Inclusion. Rider?, N.Y. Times (June 19, 2019), https://www.nytimes.com/2019/06/19/movies/inclusion-rider.html [https://perma.cc/6WC4-AWFV].

221. See Eriq Gardner, Why Hollywood's 'Inclusion Rider' Mania Could Hurt the Equality Cause, HollywOOD REP. (Mar. 15, 2018, 6:37 AM), available at https://www.hollywoodreporter.com/thr-esq/why-hollywoods-inclusion-rider-maniacould-hurt-equality-cause-1094435 [https://perma.cc/6FYR-JJ98] ("Has McDormand realized that she's put inequality in Hollywood in the hands of transactional attomeys? Surely, these folks are problem-solvers. They are also risk-averse and deal with competing interests. Plus, there are antidiscrimination laws already on the books. If there's a legal solution to inequality, what will contracts solve that statutes won't? Maybe we should address that.").

222. Tamar Megiddo, Beyond Fragmentation: On International Law's Integrationist Forces, 44 YALE J. INT'L L. 115, 116 (2019) (describing fragmentation as "inconsistent guidance received from different international legal regimes" which "place[ States in an impossible conflict, having to breach the binding norms of one regime to abide by another"). 
efforts to regulate Brazilian tire production. ${ }^{223}$ The proliferation of quasi-state actors such as the WTO system, the International Tribunal for the Law of the Sea (ITLOS), the North American Free Trade Agreement (NAFTA), and others create "an obvious concern" about "multiple tribunals addressing the same dispute, without adequate rules for dealing with overlapping jurisdiction." 224

As noted above, international law generally operates on states, and not on individuals, such as corporations. Nevertheless, it is not difficult to see the analogy to KSR. A multinational corporation may conduct business with a foreign corporation closely aligned with a host government that engages in normatively problematic behavior, for example forcibly removing ethnic or racial minorities from valuable land to enable the local company to use the land for mining. The foreign corporation may be in a supply chain agreement with the United States MNC that prohibits these sorts of activities, but it cannot perform under its contract unless it participates in these forbidden activities. The foreign corporation and, to the extent of its participation, the host state, will be subject to different competing legal regimes, one which tolerates (and may require) this conduct, and one which forbids it.

Second, even without the international overlay, KSR may increase underlying social divisions. Frances McDormand's call for inclusion riders may appeal to political progressives. But what prevents someone like Mel Gibson from using his market power to negotiate for an

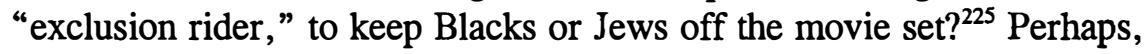
if that violates U.S. antidiscrimination law, he may contract for a term which says that the movie company will only hire Caucasian Christians. In a world in which a majority of the United States Supreme Court is increasingly deferential to the claimed religious entitlements of market actors, ${ }^{226}$ it is not difficult to imagine courts finding themselves uncertain whether to strike such terms, even if they wanted to do so.

223. Julia Ya Qin, Managing Conflicts Between Rulings of the World Trade Organization and Regional Trade Tribunals: Reflections on the Brazil - Tyres Case, in Making Transnational LaW Work IN THE Global Economy 601, 602 (Pieter H. F. Bekker, Rudolf Dolzer \& Michael Waibel eds., 2010) (describing Brazil's situation among the "worst type of conflicts" arising from fragmentation).

224. Benedict Kingsbury, Foreword: Is the Proliferation of International Courts and Tribunals a Systemic Problem?, 31 N.Y.U. J. INT'L L. \& PoL'Y 679, 683 (1999).

225. See, e.g., Arya Roshanian, Mel Gibson Opens Up About 2006 Arrest, Anti-Semitic Remarks: 'I've Never Discriminated Against Anyone,' VARIETY (Oct. 27, 2016), http://variety.com/2016/film/news/mel-gibson-interview-anti-semitic-2006arrest-podcast-1201902552/ [https://perma.cc/B9NE-NC7E].

226. Burwell v. Hobby Lobby Stores, Inc., 134 S. Ct. 2751, 2768-69 (2014) (holding that "protecting the free-exercise rights of corporations . . . protects the religious liberty of the humans who own and control those companies" and that "no 
This would bespeak a larger risk of fragmentation posed by KSR. If KSR becomes a mechanism for advancing normative regimes, there is no guarantee that all of us will support a given position. Different market actors, with conflicting views, may enter into contracts that advance conflicting normative goals. But that would then mean that KSR increases social divisions and does not necessarily reduce them.

In short, the most we can say of KSR is that it is part, but only part, of larger social and legal debates about how to create the world in which we want to live. It can be an important part-far more so than observers have recognized-but its efficacy will turn largely on the commitments that parties have made to honor the terms to which they have agreed. Other mechanisms, such as "hard" public law and even soft normative regimes, will remain important to buttress the role that KSR can play.

\section{CONCLUSION}

At this stage, KSR is too new and opaque to say with confidence whether we should despair that it is merely a cynical ploy or rejoice that it is a pathway to a more promising future. Probably, it will be some of both. This paper has been a first step in identifying some of the key contractual aspects of this phenomenon and situating them in salient literatures that have all but ignored them. This paper is not meant to be the last word on the use of contract as a form of social responsibility but, I hope, the first. 